\title{
THE USE OF REED BEDS FOR TREATMENT OF LANDFILL LEACHATES
}

\author{
Tim Robinson * and Howard Robinson
}

Phoenix Engineering, Phoenix House, Scarne Mill Industrial Estate, Launceston, Cornwall, PL15 9GL, United Kingdom

Article Info:
Received:
23 March 2018
Revised:
27 July 2018
Accepted:
16 August 2018
Available online:
6 September 2018
Keywords:
SBR
Phytotreatment
Landfill leachate treatment
Biological treatment
Effluent polishing
Reed bed treatment

\section{INTRODUCTION}

The on-site treatment of leachates has become an essential part of operations at many landfills in the UK, and at many sites reliable and cost-effective biological treatment systems have been designed and installed. Almost all of these operate as Sequencing Batch Reactors (SBRs), the first such UK system having been designed as long ago as 1982. Several papers have presented detailed operational results from such plants in recent years (Robinson et al., 2003, 2005; Robinson, 2015b; Novella et al., 2004; Carville et al., 2003; Robinson, 2003;) many of these describing plants which have made safe discharges into sensitive watercourses over many years, by use of reed beds for effective effluent polishing to high standards.

A continuing problem, however, remains the uncontrolled discharge of leachates from old landfill sites, many of which were originally engineered to standards far lower than is now acceptable. Although leachates may be relatively diluted, often because of groundwater ingress into unlined landfills, their impact on local watercourses can still be significant.

Reed bed treatment systems have found wide application as robust polishing processes after SBR treatment of raw leachates, prior to the final discharge of very high-quality effluents into watercourses (e.g. see Robinson, 1996; Robinson and Knox, 2001; 2003). However, reed beds are unable to provide good treatment of concentrations of am-
moniacal-N much greater than about 20 or $30 \mathrm{mg} / \mathrm{l}$ (Cooper, 1999; Cooper and Green, 1995; Cooper et al., 1997), especially during colder winter months. Nevertheless, at older closed landfills, where much weaker leachates may be generated and released, and where low maintenance solutions are essential, reed beds can have a role to play. This chapter provides design information for both Vertical and Horizontal Flow reed bed systems, and performance data from detailed case studies at four closed landfill sites, for which several decades of data are available.

\section{REED BED DESIGN AND OPERATIONS}

\subsection{Reed bed Design}

Reed beds are designed to pass flows of wastewater either horizontally (Figure 1), or vertically (Figure 2). For each design type, most successful applications involve subsurface flow within gravel or sand media into which reeds have been planted - avoiding surface free-water flow, which would bypass the main treatment surfaces. Horizontal Flow Reed Beds (HFRBs) receive an inflow from an overflowing halfpipe structure at the inlet end of the bed, before water flows across and through the flooded bed, at a depth which can be adjusted by means of an adjustable overflowing outlet. Single-size gravel media (typically $10 \mathrm{~mm}$ pea gravel) is generally flooded to just below the gravel surface, avoiding surface flows bypassing treatment, and allowing water to flow horizontally, at a steady rate. 
In a Vertical Flow Reed Bed (VFRB), the packing media can be a range of sizes, and water levels in the bed vary during treatment cycles. Incoming leachate, or pre-treated leachate, enters as occasional 'slug' doses (ideal for use in combination with SBR pre-treatment, where biological effluent is discharged in batches), and floods the bed surface. The liquid gradually passes down through the bed, contacting oxygen in the spaces between the media particles. The bed becomes fully flooded, and effluent continuously drains from the bottom of the bed at a controlled rate. As the liquid drains out, fresh air, containing oxygen, is drawn down into the media of the bed. Eventually the bed drains completely, ready for another dose of feed. Vertical flow beds therefore have greater oxygen inputs, so can provide more treatment (e.g. nitrification of ammoniacal-N) but are usually not so good at solids removal (Morris and Herbert, 1997).

\subsection{Contaminant removal mechanisms within reed beds}

The types of reed beds in case studies described below are four lined, gravel-filled, horizontal flow beds, and one combined system with both vertical and horizontal beds used to polish leachates that have been pre-treated in a modified SBR process. The four UK reed beds discussed in this paper are as follow; Monument Hill Landfill (Devizes), Shirley Landfill (West Midlands), Efford Leachate Treatment Plant (Hampshire), and Small Dole Leachate Treatment Plant (West Sussex).

Reeds, Phragmites Australis, have been planted into the gravel at each site. Effluent enters at the inlet of the beds, travelling slowly through the bed following a horizontal flow-path, before overflowing via a level control device. Although vertical flow reed beds have been reported to provide higher rates of removal of ammoniacal- $\mathrm{N}$, their reduced performance in achieving removal of solids, and the intrinsic simplicity of the horizontal bed, were key to horizontal beds being selected at each site below.

Iron and suspended solids are readily removed in a reed bed system, principally by oxidation and physical filtration processes. The rhizome system of the reeds within the gravel bed may contribute to improved performance, by enhancing the supply of oxygen available by passive diffusion, which is required to convert soluble iron to insoluble

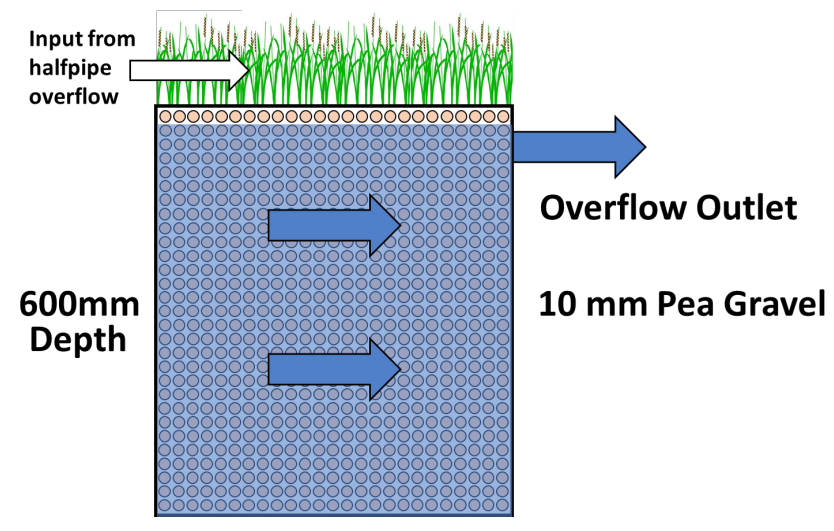

FIGURE 1: Cross-section of a horizontal flow reed bed. iron hydroxide.

Reed beds are particularly good at removing methane from effluents by means of aerobic biological degradation. Methane is readily oxidised biologically by bacteria, in the presence of oxygen. Therefore, because oxygen enters the reed beds by passive diffusion, assisted to some extent by oxygen transfer via the reed plants, methane can be removed successfully. This removal has been demonstrated at a reed bed at Shirley Landfill Site in the UK, where dissolved methane levels must satisfy a $0.14 \mathrm{mg} / \mathrm{l}$ discharge consent (see Robinson, 2017a).

Although reed beds have a poor record for removal of ammoniacal nitrogen from effluents containing high levels of COD and BOD (for example, widely noted for direct treatment of domestic wastewaters), they are generally more successful in situations where concentrations of organic contaminants are much lower, (as in the Monument Hill leachate, or for biologically pre-treated leachates), and more oxygen is therefore available to nitrifying organisms, principally Nitrosomonas and Nitrobacter, which convert ammoniacal nitrogen to nitrite, and then to nitrate. The fullscale case studies provide detailed design and operational information.

\section{MONUMENT HILL LANDFILL}

\subsection{Background}

Monument Hill Landfill Site is an infilled valley, $2 \mathrm{~km}$ east of the town of Devizes, Wiltshire, in Southern England, and was filled with household wastes during the 1970s, and is unlined, with a culverted stream beneath the landfill in the valley bottom. The $10-15 \mathrm{~m}$ overburden of wastes previously caused failure of the culvert, resulting in contamination of the stream over many years.

In 1985, to improve this situation significantly, a new culvert was prepared to divert the stream around the landfill, but the old culvert remained in place and caused continuing, albeit substantially reduced, minor downstream pollution of the Stert watercourse downstream of the site (see Figure 3). In 1992, after a detailed monitoring exercise, a reed bed leachate treatment scheme was installed on top of the old landfill, capable of treating up to $300 \mathrm{~m}^{3}$ of leachate per day, and compatible with the nature reserve in which the restored site is located (Robinson et al., 2007).

As the site is remote, closed and unmanned, a low maintenance, low cost, vandal-resistant system was required for treatment of pumped leachate flows, which were typically in the range $200-300 \mathrm{~m}^{3} / \mathrm{d}$. Based on physical constraints posed by the site, and wildlife sensitivity, the only area available for construction was over-infilled parts of the site, and based on required effluent standards indicated by the Environment Agency, an engineered reed bed scheme was developed.

\subsection{Leachate quality}

An intensive programme of monitoring of the site began during Autumn 1993, to complement the long period during which samples of leachate had been taken by Wiltshire County Council prior to this. Monitoring included continuous measurement and recording of flows of leachate, 
Stage 1: No Flow, quiet phase

Splash pad setup

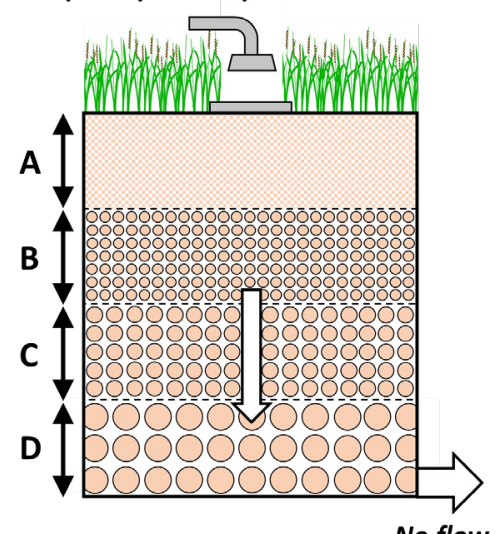

Stage 2: Reedbed flooded
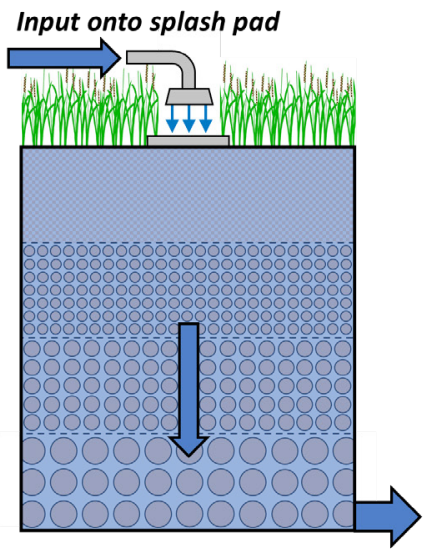

Free draining output
Stage 3: Reedbed drained
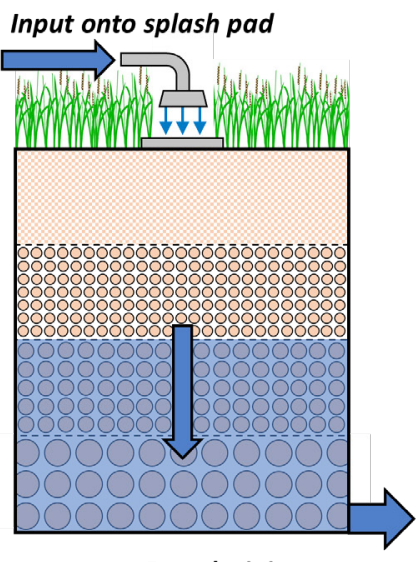

Free draining output

$A=$ Sharp Sand, $B=6 \mathrm{~mm}$ Pea Gravel, $C=12 \mathrm{~mm}$ Round Gravel, $D=30-60 \mathrm{~mm}$ Round Stone

FIGURE 2: Cross-section of a vertical flow reed bed.

and of the flow within the Stert Watercourse.

Water samples were routinely obtained and tested, and results are summarised in Table 1.

Contaminants present in the leachate discharge, considered to have continuing potential for significant adverse impact on the Watercourse, were iron, suspended solids, and ammoniacal-N. Iron was unlikely to be a health concern; its main impact being the orange staining that was evident for a distance of $10 \mathrm{~m}$ below the discharge point. Levels of suspended solids in leachate, associated to some extent with particulate iron, were typically about $60 \mathrm{mg} / \mathrm{l}$, and needed to be reduced. Ammoniacal-nitrogen

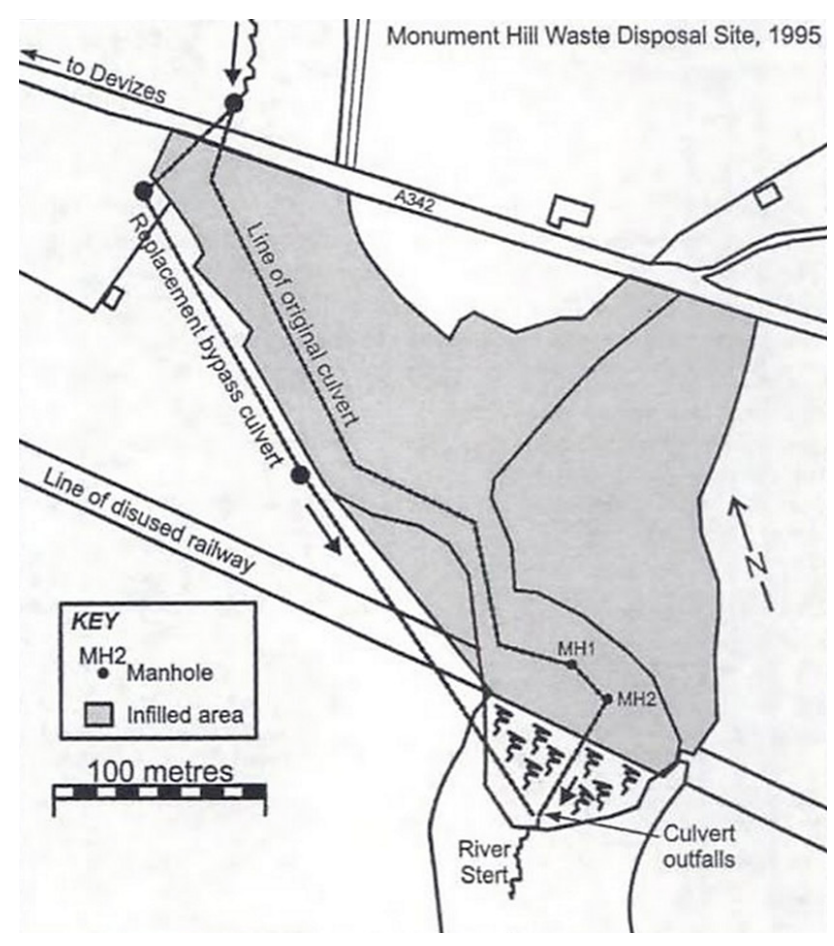

FIGURE 3: Monument Hill waste disposal site in 1995, prior to implementation of remedial works (after Robinson et al., 2007). was of concern due to its potential toxic effect on aquatic organisms, salmonid fish, such as trout, being particularly sensitive.

Leachate analyses determined that concentrations of up to $19 \mu \mathrm{g} / \mathrm{l}$ Mecoprop (MCPP) (a phenoxy alkanoic herbicide) were also present in the leachate flows (values as high as $0.6 \mu \mathrm{g} / \mathrm{l}$ were also measured in the upstream Stert Watercourse, presumably of agricultural origin). Even though mecoprop is of low toxicity to mammals, fish, and insects, and is readily and completely degraded in aerobic situations such as soil (Heron and Christensen,1992), UK guidance states that it should not be applied near to watercourses. In the light of the above, it was considered likely that treatment would significantly reduce the concentrations of MCPP entering the stream.

Toxic trace metals are often stated to be of concern by regulators in dealing with discharges of raw or treated landfill leachates, either for treatment in sewage works, or directly into surface watercourses. Previous research has demonstrated that the speciation of metals within landfill leachates is the main contributing factor as to the toxicity of several trace metals within leachates (Jensen et al., 1999; Baun and Christensen, 2004).

Jensen and Christensen (1999) stated that in leachates, concentrations of some heavy metals can be very low, whilst further research work has demonstrated that heavy metals are rarely found at significant levels in any methanogenic leachates, unless the landfills have received specific direct inputs of such metals within incoming waste streams (e.g. Robinson, 1996; Robinson and Knox, $2001 ;$ 2003). No significant concentrations were detected in samples of leachate at Monument Hill (Table 1).

Presentation and discussion of monitoring results with the Environment Agency, including specific discussion of ammoniacal nitrogen removal, led to the Agency defining the discharge consent conditions as follows:

- $\operatorname{BOD}(10 \mathrm{mg} / \mathrm{l})$;

- ammoniacal nitrogen (23 mg/l); 
TABLE 1: Summary of design data for leachate quality entering the HFRB at Monument Hill Landfill site, December 1993 to October 1994.

\begin{tabular}{|c|c|c|c|c|c|}
\hline Determinand & Units & Samples & Mean & Min & Max \\
\hline pH-value & $\mathrm{pH}$ & 14 & 7.1 & 6.8 & 7.8 \\
\hline COD & $\mathrm{mg} / \mathrm{l}$ & 22 & 43.6 & 25 & 64 \\
\hline $\mathrm{BOD}_{5}$ & $\mathrm{mg} / \mathrm{l}$ & 21 & $<5$ & 1.4 & 5.0 \\
\hline Ammoniacal-N & $\mathrm{mg} / \mathrm{l}$ & 21 & 25.5 & 16.7 & 31 \\
\hline Chloride & $\mathrm{mg} / \mathrm{l}$ & 20 & 94.7 & 83 & 108 \\
\hline Suspended solids & $\mathrm{mg} / \mathrm{l}$ & 14 & 57.5 & 50 & 70 \\
\hline Conductivity $(\mu \mathrm{S} / \mathrm{cm})$ & $\mu \mathrm{S} / \mathrm{cm}$ & 7 & 1,330 & 1,210 & 1,472 \\
\hline Sulphate $\left(\mathrm{as} \mathrm{SO}_{4}\right)$ & $\mathrm{mg} / \mathrm{l}$ & 6 & 48.3 & 26 & 86 \\
\hline Phosphate (as P) & $\mathrm{mg} / \mathrm{l}$ & 2 & 0.3 & - & 0.3 \\
\hline Sodium & $\mathrm{mg} / \mathrm{l}$ & 7 & 59.3 & 54 & 67 \\
\hline Magnesium & $\mathrm{mg} / \mathrm{l}$ & 7 & 16.8 & 15 & 20 \\
\hline Potassium & $\mathrm{mg} / \mathrm{l}$ & 12 & 31.8 & 26 & 36.4 \\
\hline Calcium & $\mathrm{mg} / \mathrm{l}$ & 12 & 215 & 196 & 235 \\
\hline Chromium & $\mathrm{mg} / \mathrm{l}$ & 7 & $<0.1$ & $<0.01$ & $<0.1$ \\
\hline Manganese & $\mathrm{mg} / \mathrm{l}$ & 13 & 0.81 & 0.5 & 0.99 \\
\hline Iron & $\mathrm{mg} / \mathrm{l}$ & 20 & 21.2 & 12 & 28 \\
\hline Nickel & $\mathrm{mg} / \mathrm{l}$ & 7 & $<0.05$ & $<0.01$ & $<0.05$ \\
\hline Copper & $\mathrm{mg} / \mathrm{l}$ & 7 & $<0.05$ & $<0.01$ & 0.03 \\
\hline Zinc & $\mathrm{mg} / \mathrm{l}$ & 18 & 0.08 & 0.05 & 0.11 \\
\hline Cadmium & $\mathrm{mg} / \mathrm{l}$ & 8 & $<0.02$ & $<0.002$ & $<0.01$ \\
\hline Lead & $\mathrm{mg} / \mathrm{l}$ & 7 & $<0.05$ & $<0.01$ & 0.02 \\
\hline Arsenic & $\mathrm{mg} / \mathrm{l}$ & 1 & 0.005 & - & 0.005 \\
\hline Mecoprop & $\mu \mathrm{g} / \mathrm{l}$ & 15 & 5.34 & 1.06 & 18.91 \\
\hline
\end{tabular}

- $\operatorname{iron}(6.5 \mathrm{mg} / \mathrm{l})$;

- $\quad$ suspended solids (25 mg/l).

Remedial works comprised a new sump to intercept leachate flows, a settlement chamber to remove precipitated iron, and an $1,800 \mathrm{~m}^{2}$ area of lined, $600 \mathrm{~mm}$ deep, gravel-filled Horizontal Flow Reed Bed, for degradation of low levels of BOD and mecoprop. Some reduction in concentrations of ammoniacal nitrogen was also anticipated, especially during warmer summer months, when the watercourse, which receives the final effluent, is most sensitive, but was not generally required by the consent, which took account of dilution available within the receiving watercourse.

\subsection{Leachate flows}

Flows within the diverted Stert Watercourse (which would receive treated leachate from the site), and of leachate draining from the landfill via the old culvert, were continuously monitored during an initial twelve-month investigation period. Figure 4 is a plot of the relationship between measured daily flows in the Stert Watercourse (range 1,000 to $4,000 \mathrm{~m}^{3} / \mathrm{d}$ ), and daily flows of leachate from the old culvert (range 60 to $300 \mathrm{~m}^{3} / \mathrm{d}$ ). Results demonstrated that during 1994 the minimum dilution available at any time was at least $5: 1$. Dilution exceeded $6: 1$ more than $99 \%$ of the time; and exceeded $10: 1$ for $70 \%$ of the time. This fact was considered in the design of remedial works.
Rainfall records clearly demonstrated that flows of leachate from the old landfill were not rainfall dependent. It was calculated that mean infiltration rates through the old landfill surface were likely to lie in a range between 25 and $33 \mathrm{~m}^{3}$ per day, compared with flows of leachate, which were typically between 180 and $220 \mathrm{~m}^{3} / \mathrm{d}$. It was therefore concluded that most of the leachate being discharged via the old culvert almost certainly represented groundwater inflows into wastes, and the drainage system in the landfill base. Efforts were therefore concentrated on treatment of leachates, rather than in trying to reduce volumes being generated.

\subsection{Design and construction of the reed bed}

The Horizontal Flow Reed Bed was sized using experience gained from an experimental reed bed designed that had successfully polished effluent from a leachate treatment plant at Compton Bassett, Wiltshire (Robinson, 1993). Being pre-treated, that effluent had a low BOD, similar to that of raw leachate at Monument Hill. The Compton Bassett bed was therefore extrapolated to give a required bed size of $1,800 \mathrm{~m}^{2}$ at Monument Hill. $10 \mathrm{~mm}$ single-sized pea gravel, placed to a depth of $600 \mathrm{~mm}$, and with a porosity of about $40 \%$, provided the required $2-3$ days hydraulic retention time. This size of bed resulted in an iron loading rate of $4 \mathrm{~g} / \mathrm{m}^{2} / \mathrm{d}$, which was considered adequate, with additional spare capacity to account for the bed possibly becoming clogged with iron deposits over time. 


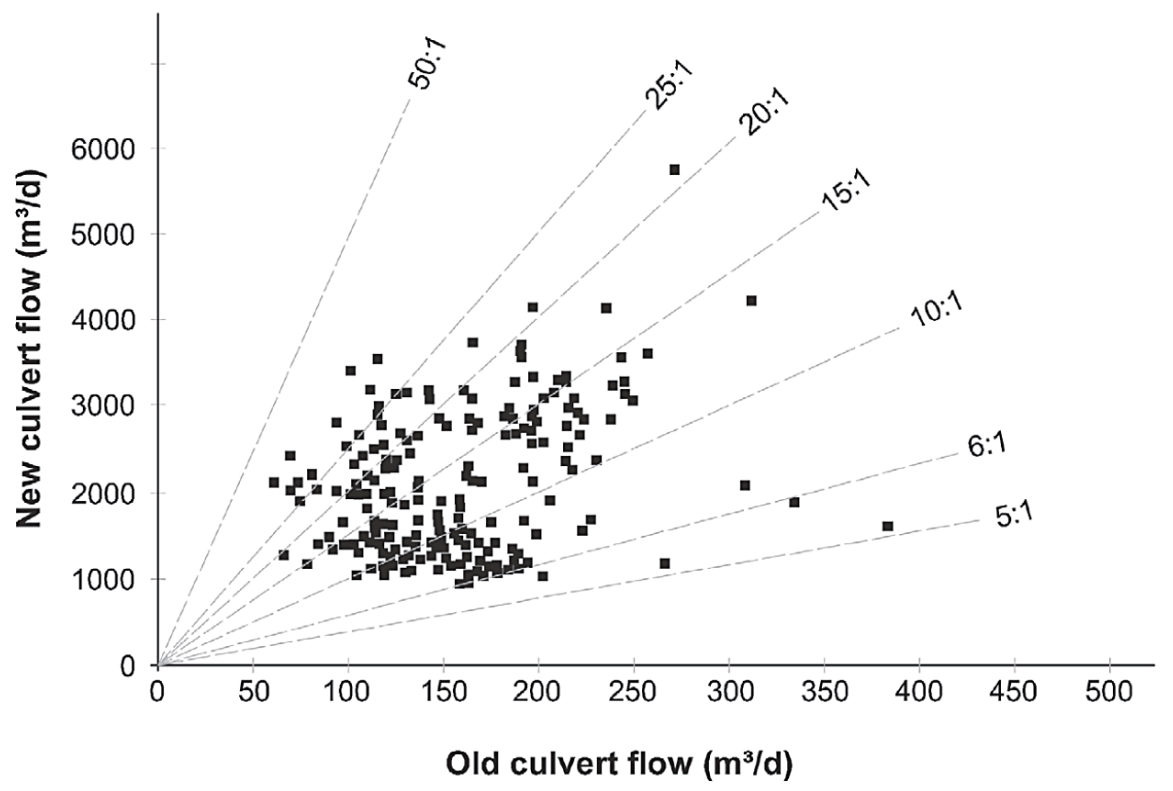

FIGURE 4: Comparison of total measured daily flows in the old and new culvert outfalls at Monument Hill landfill site during 1994 (results in $\mathrm{m}^{3} / \mathrm{d}$ ) (as presented in Robinson et al., 2007). Lines represent degree of dilution available within the watercourse.

In recognition of the fact that the reed bed would gradually accumulate precipitated iron, a preliminary settlement tank was included at the front end of the bed, to be cleaned out occasionally, by vacuum tanker.

Table 2 summarises the raw leachate quality used for design purposes. The reed bed, was completed during July 1996, lined with $2.5 \mathrm{~mm}$ HDPE with a geofabric protection layer, and filled with $600 \mathrm{~mm}$ of gravel (Figure 5). It was planted with 20,000 $9 \mathrm{~cm}$ pot-grown plants of Phragmites australis. Water levels were initially maintained at the surface of the gravel, to avoid short-circuiting of flows, and to discourage weed growth, but then reduced by a few centimetres for final operation.

\subsection{Performance of the Monument Hill Reed bed}

Table 3 presents results obtained from analysis of samples taken 8 weeks after commissioning. The removal of iron could be traced through the system, with $28 \%$ being removed in the settling tank, and the remainder being removed within the reed bed, resulting in the iron concentrations in final effluent discharge being reduced to below detection limits. The header tank had no effect on the concentration of ammoniacal-N, and was not expected to. The removal rate for ammoniacal- $\mathrm{N}$ within the reed bed was $40 \%$, with subsequent dilution within the Watercourse oc-

TABLE 2: Results from analysis of samples taken from the old culvert at Monument Hill landfill site, on 8 January 1996 (results in $\mathrm{mg} / \mathrm{l})$.

\begin{tabular}{l|c|c|c} 
Determinand & Total leachate & Filtered on-site & $\begin{array}{c}\text { Filtered @ 24 } \\
\text { hours }\end{array}$ \\
\hline COD & 47 & 47 & 47 \\
\hline BOD $_{5}$ & 3 & 3 & $<2$ \\
\hdashline Ammoniacal-N $^{\prime}$ & 19.2 & 18.9 & 19.4 \\
\hline Iron & 16.6 & 14.3 & $<0.6$ \\
\hline
\end{tabular}

curring at the agreed effluent discharge point.

Chloride values demonstrated that the removal of iron, ammoniacal nitrogen and mecoprop in the reed bed were not due to dilution. The removal of mecoprop by the reed bed, from $10.5 \mu \mathrm{g} / \mathrm{l}$ in the influent, to $2.68 \mu \mathrm{g} / \mathrm{l}$ in the effluent was extremely encouraging at such an early stage in the commissioning of the scheme.

Figure 6 presents initial results for the concentrations of suspended solids in treated leachate being discharged to the Stert Watercourse, in samples taken from April 1994 to December 1999. A dramatic and immediate improvement in levels of suspended solids entering the stream from the landfill was evident as soon as operation of the reed bed

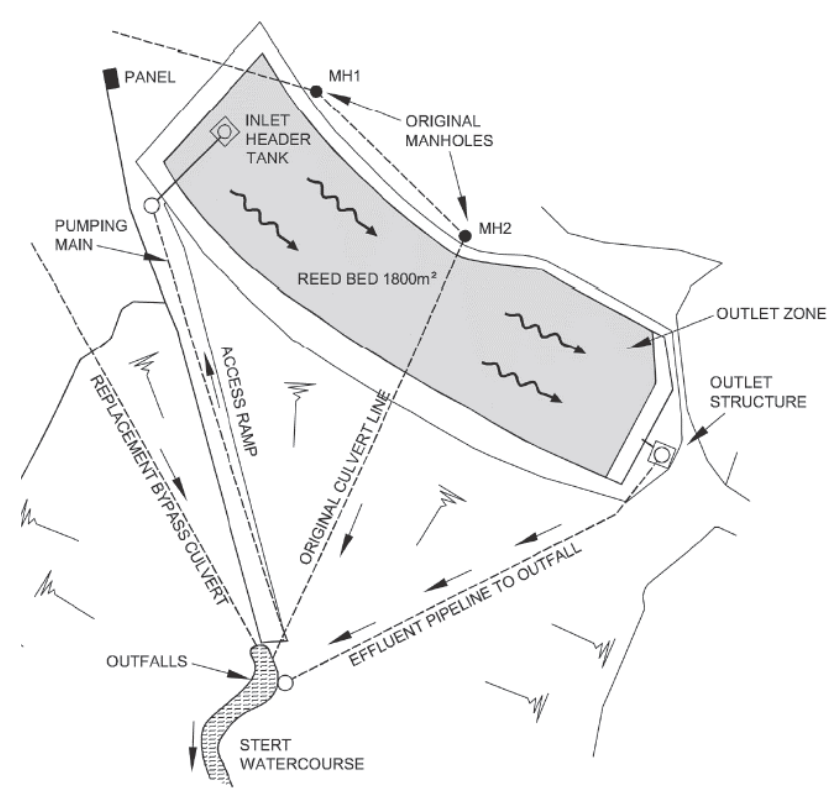

FIGURE 5: Layout of the reed bed at Monument Hill Landfill (Robinson et al., 2007). 
TABLE 3: Initial results from analysis of sample from various locations at Monument Hill, in September 1996, soon after introduction of the reed bed scheme.

\begin{tabular}{|c|c|c|c|c|c|c|}
\hline Determinand & Units & $\begin{array}{c}\text { Raw } \\
\text { Leachate }\end{array}$ & $\begin{array}{l}\text { After Settling } \\
\text { Tank }\end{array}$ & $\begin{array}{l}\text { Reed Bed } \\
\text { Effluent }\end{array}$ & $\begin{array}{c}\text { Upstream } \\
\text { Watercourse }\end{array}$ & $\begin{array}{l}\text { Agreed Downstream } \\
\text { Sampling Point }\end{array}$ \\
\hline $\mathrm{pH}$ value & $\mathrm{pH}$ & 6.8 & 6.9 & 7.4 & 8 & 7.6 \\
\hline $\mathrm{BOD}_{5}$ & $\mathrm{mg} / \mathrm{l}$ & $<2$ & $<2$ & $<2$ & $<2$ & $<2$ \\
\hline Ammoniacal-N & $\mathrm{mg} / \mathrm{l}$ & 19.4 & 19.6 & 11.8 & $<0.3$ & 1.8 \\
\hline Iron & $\mathrm{mg} / \mathrm{l}$ & 16.9 & 12.2 & $<0.6$ & $<0.6$ & 0.7 \\
\hline Suspended solids & $\mathrm{mg} / \mathrm{l}$ & 42 & 42 & 3 & 19 & 16 \\
\hline Chloride & $\mathrm{mg} / \mathrm{l}$ & 78 & 77 & 76 & 23 & 32 \\
\hline Mecoprop & $\mu \mathrm{g} / \mathrm{l}$ & 9.4 & 10.5 & 2.68 & $<0.1$ & 0.44 \\
\hline
\end{tabular}

began in July 1996, with concentrations falling from about 50 or $100 \mathrm{mg} / \mathrm{l}$ in leachate, to levels rarely above $10 \mathrm{mg} / \mathrm{l}$ in effluent. This improvement has continued for more than 10 years (see Figure 7). Data demonstrate that although high levels of solids remain present in leachate, and sometimes in the Stert Watercourse, levels in treated leachate continue to rarely exceed $10 \mathrm{mg} / \mathrm{l}$.

Introduction of the reed bed immediately effected reliable and almost complete removal of iron, generally to background concentrations. Removal of iron during the initial 10-year period of reed bed operation is summarised in Figure 8, where essentially complete removal of iron has continued to be achieved by the combination of the preliminary settlement tank, (desludged as required, approximately once per year) and the bed itself. After 10 years there was no evidence that accumulation of iron within the bed had caused any reduction in treatment performance whatsoever. In addition, levels of iron in raw leachate have gradually fallen, to values typically between $5-18 \mathrm{mg} / \mathrm{l}$.

Figure 9 contains equivalent early data for ammonia-

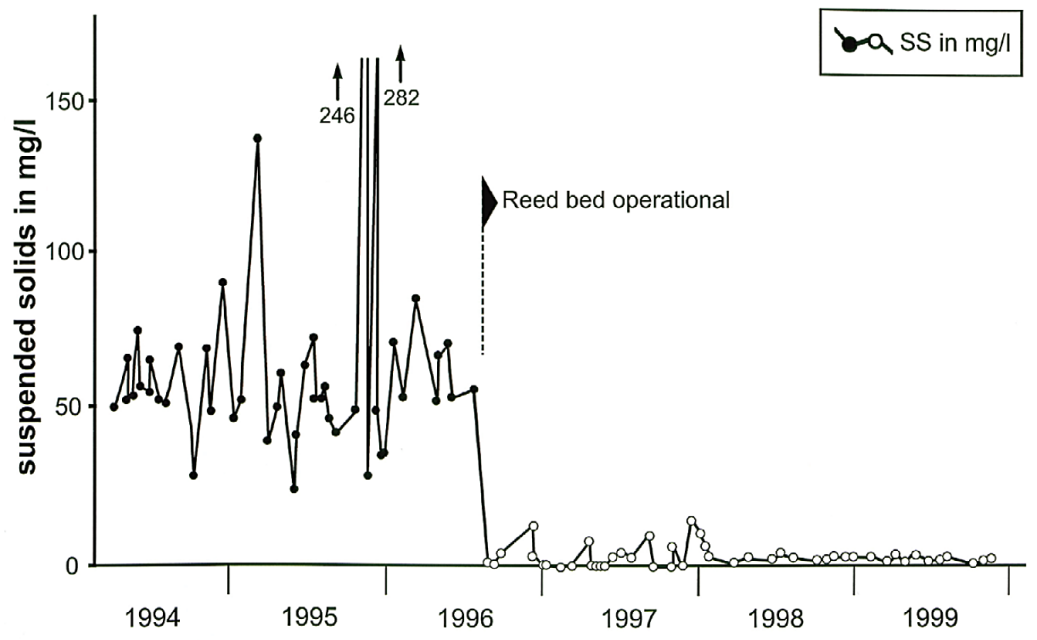

FIGURE 6: Concentrations of suspended solids in the discharge to the Stert Watercourse, 1994-1999 (Robinson et al., 2007).

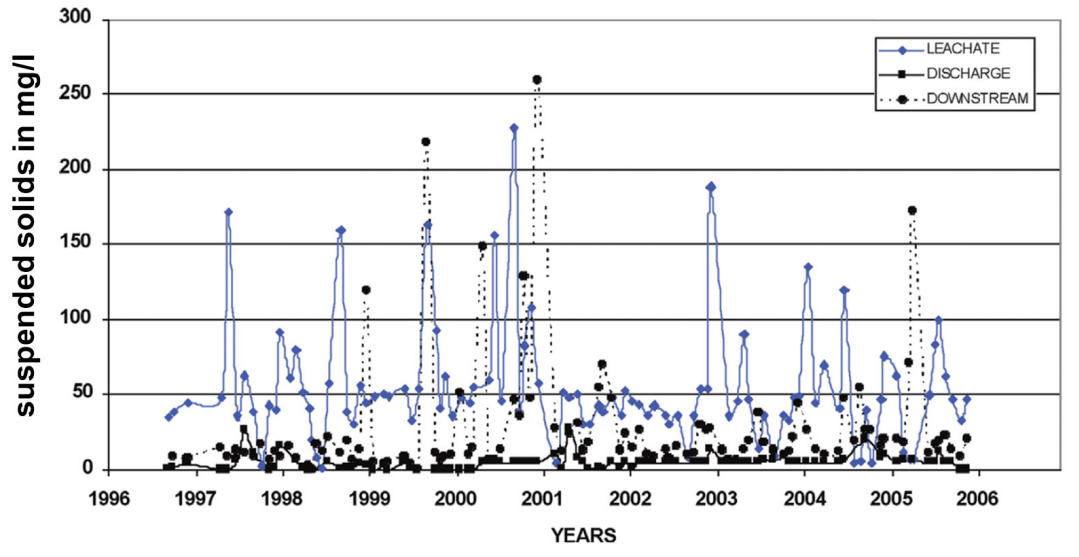

FIGURE 7: Concentrations of suspended solids in leachate, treated effluent, and downstream of the Monument Hill reed bed, within the Stert Watercourse, 1996 to 2006 (Robinson et al., 2007). 
cal-N. Results for ammoniacal-N in leachate had historically shown slightly elevated concentrations (typically 25-30 $\mathrm{mg} / \mathrm{l}$ ) during summer months, compared with values near to $20 \mathrm{mg} / \mathrm{l}$ during winter months. Introduction of the reed bed in July 1996 resulted in a significant and consistent reduction of about $50 \%$ in concentrations of ammoniacal-N, typically to between 10 and $15 \mathrm{mg} / \mathrm{l}$.

Results demonstrate that, during an extended period from 1996 to 2006, not only did concentrations of ammoniacal- $\mathrm{N}$ in leachate fall to some extent (presently 15-20 $\mathrm{mg} / \mathrm{l})$, but removal rates during treatment in the bed have also improved. Typically, between 50 to $70 \%$ of incoming ammoniacal- $\mathrm{N}$ is removed, leaving between 3 and $10 \mathrm{mg} / \mathrm{l}$ of ammoniacal-N in effluent discharged from the reed bed into the watercourse. Dilution available within the Watercourse, as anticipated, has meant that concentrations of ammoniacal- $\mathrm{N}$ in the stream below the landfill rarely exceed 1 or $2 \mathrm{mg} / \mathrm{l}$.

Although there is evidence of increased concentrations of nitrate after treatment in the bed, this does not account for all of the removal of ammoniacal- $N$ being observed. Other processes such as uptake into the reeds, or some denitrification, must therefore be taking place. Although no consistent records of volumes of leachate being treated in the reed bed are now being kept, evidence from occasional flow monitoring and pumping records, indicate that flows of $100-200 \mathrm{~m}^{3} / \mathrm{d}$ remain typical. At these flow rates during the last 5 or 6 years, reductions in concentration of 10-12 $\mathrm{mg} / \mathrm{l}$ of ammoniacal-N are common (higher removal during summer months), allowing a range of removal rates in terms of grams of ammoniacal- $\mathrm{N}$ removed per $\mathrm{m}^{2}$ of bed area to be estimated broadly as follows:

\section{- Summer: 0.65-1.35 gN/m²/day}

- Winter: $0.55-1.10 \mathrm{gN} / \mathrm{m}^{2} /$ day

Concentrations of mecoprop in leachate have remained at generally similar levels throughout the period 1994-2006, typically 4-8 $\mu \mathrm{g} / \mathrm{l}$. Treatment in the reed bed has always kept concentrations in effluent below $2 \mu \mathrm{g} / \mathrm{l}$. Results for chloride in leachate give a general indication of changes in raw leachate strength at Monument Hill, and show that although this remained fairly stable from 1994 to late 1999, since that time values have reduced by about $25 \%$. Chloride levels remain unaffected by passage through the reed bed, as would be expected. COD removal in the bed has typically been about $15-20 \%$ because of low levels of degradable or-

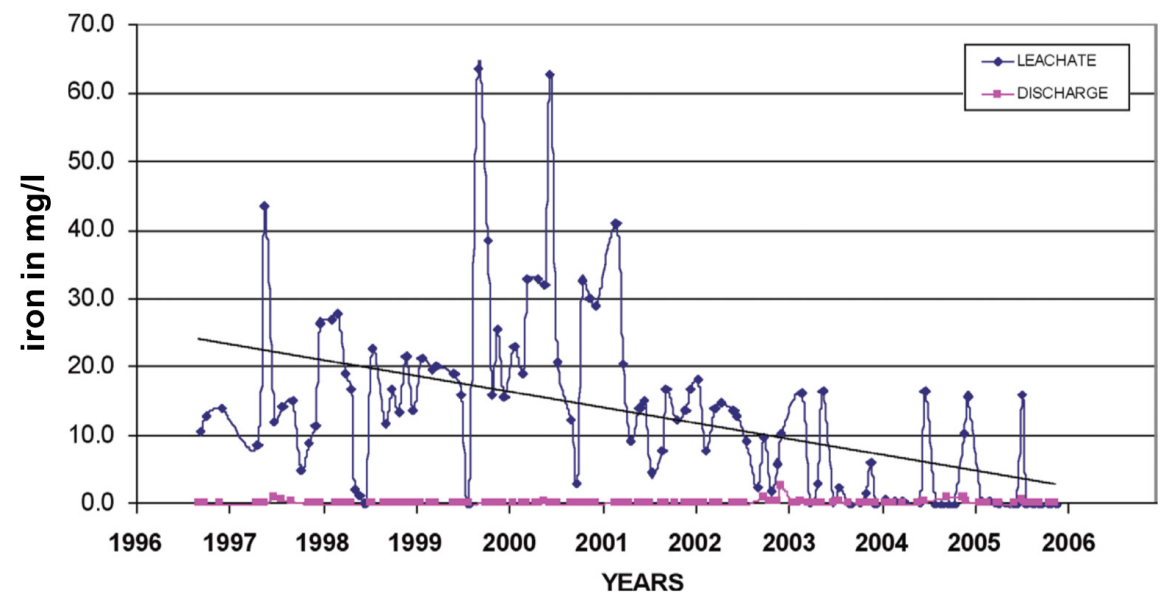

FIGURE 8: Removal of iron after passage through the Monument Hill reed bed, 1996-2006 (as presented in Robinson et al., 2007).

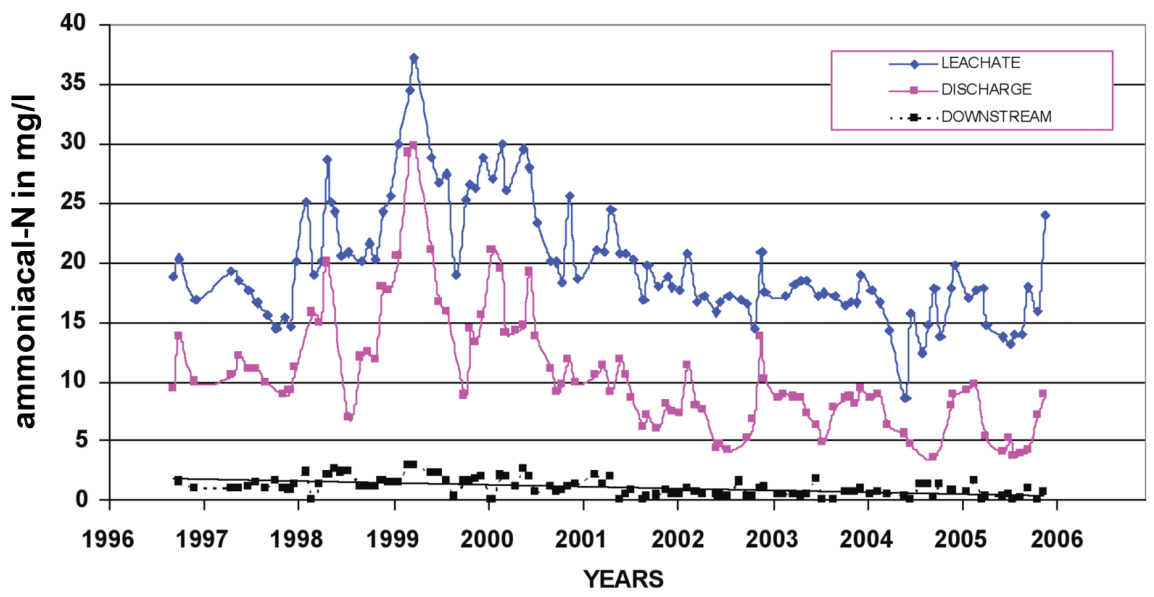

FIGURE 9: Concentrations of ammoniacal-N in raw leachate, in treated leachate, and in the downstream watercourse from the Monument Hill reed bed, 1996-2006 (as presented in Robinson et al., 2007). 
ganic matter present in the methanogenic leachate.

\subsection{Performance}

Analytical results demonstrate that after twenty years, the leachate treatment scheme continues to provide reliable, efficient, and cost-effective protection of the watercourse. Accumulation of iron within the bed, meant that refurbishment was required during 2010, during which gravel was extracted, washed, replaced and replanted, but treatment has since continued to achieve required consents adequately (see Table 4).

\section{SHIRLEY LANDFILL}

\subsection{Background}

Shirley Landfill Site is located South West of the city of Birmingham, in the UK Midlands, and is the responsibility of Worcestershire County Council. The site was originally quarried for sand and gravel during the 1970s, and was restored between 1981 and 1988 by filling with $1.2 \mathrm{M} \mathrm{m}^{3}$ of household wastes, over an area of 15 hectares. The average depth of the waste is about $8 \mathrm{~m}$ with a maximum of 12 $\mathrm{m}$ and a minimum of $3 \mathrm{~m}$.

A reed bed at Shirley was designed and constructed during 2013, primarily to reduce concentrations of methane in leachate draining by gravity from the landfill, where it was recognised that uncontrolled inflow of groundwater was a significant contributor to leachate generation rates. Concentrations of dissolved methane were routinely exceeding a recently-imposed limit of $0.14 \mathrm{mg} / \mathrm{l}$, and removal would take place by means of aerobic biological degradation, since methane is readily oxidised biologically by bacteria, in the presence of oxygen. Oxygen would enter the reed bed by passive diffusion, assisted to some extent by oxygen transfer via the reed plants. Four years' data are available to demonstrate not only successful removal of methane (which is discussed in detail elsewhere, see Robinson, 2017a), but also provide valuable information on the limited and seasonal removal of ammoniacal- $\mathrm{N}$ being achieved by the bed.

\subsection{Design and construction of the reed bed}

The design was based on flow information provided by the Council; that mean flow rate would be about $50 \mathrm{~m}^{3} / \mathrm{d}$, and within a range from $24 \mathrm{~m}^{3} / \mathrm{d}$ to a maximum flow of 78 $\mathrm{m}^{3} / \mathrm{d}$. Leachate draining from the site is captured by a series of French drains and a pipeline that runs to a chamber within the site, before being discharged into the public sewer. On a number of occasions, the limit set by the discharge

TABLE 4: Performance of the Monument Hill Reedbed during 2016 (10 samples).

\begin{tabular}{|c|c|c|}
\hline Determinand & Reedbed outflow & $\begin{array}{l}\text { Downstream } \\
\text { Watercourse }\end{array}$ \\
\hline BOD & 1.5 & 2.75 \\
\hline iron & 0.56 & 0.11 \\
\hline ammoniacal-N & 15.1 & 1.33 \\
\hline
\end{tabular}

Notes: results expressed represent mean value of 10 samples taken during 2016. consent for dissolved methane was being exceeded, which had the potential to be hazardous.

As at Monument Hill, uncontrolled inflow of groundwater was a significant contributor to leachate generation rates. A reed bed was a far more sustainable and practical option for an unmanned, relatively remote, closed landfill site, than a mechanical methane stripping arrangement, and it was recognised that the development was necessary to avoid pollution, and that the only alternative would have been to take leachate off-site in tankers, generating traffic and causing amenity impacts.

There was no means of buffering gravity leachate flows from the landfill, and the reed bed design did not seek to provide any flow buffering. Results indicated that although flow rates showed seasonal variation, they did not respond rapidly to rainfall events; as might be expected from a landfill where significant groundwater inflows were involved (Robinson et al., 2015a).

Leachate transfer arrangements required modification, with construction of a new deep chamber into which leachate would now drain from the site by gravity, and from where it would be pumped by duty/standby pumps into a surface-mounted precast concrete Header Tank, having a volume of $5 \mathrm{~m}^{3}$. This header tank was designed to encourage the quiescent settlement and retention of any silt or precipitated iron solids, with supernatant leachate overflowing to the reed bed inlet.

The reed bed has a length of $50 \mathrm{~m}$, a width of $7 \mathrm{~m}$, a gravel depth of $0.6 \mathrm{~m}$, and an estimated hydraulic volume of about $85 \mathrm{~m}^{3}$, giving a mean hydraulic retention time (HRT) of between 1 and 2 days at anticipated flow rates. Effluent from the bed drains into a discharge chamber at its remote end, over a variable level control mechanism, which maintains water level within the bed just below the gravel surface. Plate 1 gives an overview of the reed bed treatment system.

\subsection{Performance}

The reed bed performs well, removing all methane from leachate entering it on most occasions, including when flows were more than double design rates during early 2014. However, of main interest, are data for removal of ammoniacal-N. Since the bed was commissioned in July 2013, routine sampling of raw and treated leachates has been carried out regularly, and all flow meters and record-

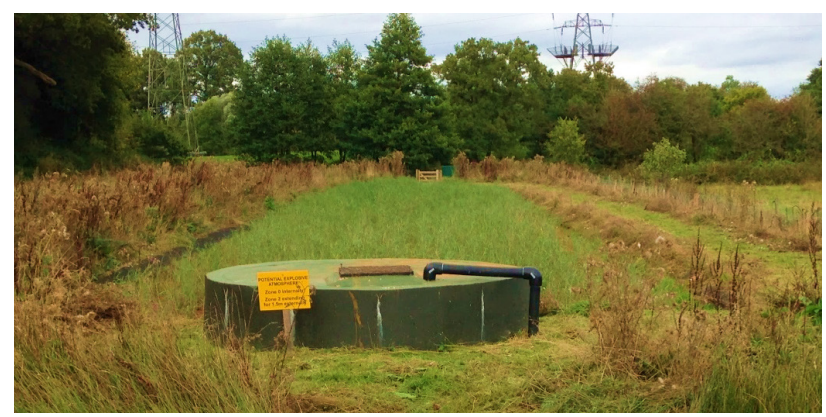

PLATE 1: General view of Shirley Reedbed from the inlet end, showing the Leachate Header Tank in the foreground, September 2014. (Robinson, 2017a). 
ing instruments have performed accurately and reliably.

Having observed loading rate data for removal of ammoniacal-N, it is evident that some seasonal removal of ammoniacal-N is taking place. However, this was not part of the original design purpose of the bed.

The most significant impact on operation of the bed, since it was commissioned, has been the flows of leachate passing through it, which have exceeded the original design specification. Extreme and record-breaking levels of rainfall during the early months of 2014 , with more than double average rainfall amounts during January and February, led to the bed receiving and treating leachate flows as high as $160 \mathrm{~m}^{3} / \mathrm{d}$, with highest values recorded during late February/early March 2014 (see Figure 10).

During the full year from 1 October 2013 to 30 September 2014, mean leachate flow rate was just over $65 \mathrm{~m}^{3} / \mathrm{d}$; 30 per cent greater than predicted values, and maximum flow rate of $163 \mathrm{~m}^{3} / \mathrm{d}$ was more than double the anticipated maximum flow rate of $78 \mathrm{~m}^{3} / \mathrm{d}$.

During the first 3 months of 2014, more than $10,000 \mathrm{~m}^{3}$ of leachate passed through the bed $\left(10,348 \mathrm{~m}^{3}\right)$, at a mean flow rate of $115 \mathrm{~m}^{3} / \mathrm{d}$, with a maximum monthly flow of $3,766 \mathrm{~m}^{3}$ during February 2014 (mean rate $134.5 \mathrm{~m}^{3} / \mathrm{d}$ ); 45 per cent greater than predicted maximum instantaneous flow rates, throughout the month.

Table 5 presents the criteria for the discharge consent, as set by Severn Trent Water Limited, for discharges of effluent from the Shirley Reed Bed. The maximum volume of effluent to be discharged to sewer, was set at $137 \mathrm{~m}^{3}$ during any single 24-hour period.

Results comparing concentrations of various contaminants in incoming leachate flows are compared with values determined in treated leachate discharged to sewer, in Figures 11 to 13. Results for chloride in raw and treated leachate are presented in Figure 11.

These results confirm that no significant dilution or concentration of contaminants took place during passage of leachate through the reed bed, which means that changes in concentrations of other contaminants can entirely be attributed to treatment being provided by biological and chemical changes taking place within the bed.

Of interest is the fact that although flow rates of leachate from Shirley Landfill, increased substantially during early 2014 , this was not associated with equivalent dilution of the leachate being received for treatment. This is characteristic of landfills where high proportions of leachate being produced are derived from groundwater inflows.

\subsection{Other contaminants}

Reed bed performance in terms of removal of other contaminants is discussed below. Figure 12 examines changes in COD values through the bed, which were minimal. Figure 13 presents results for ammoniacal-N in raw and treated leachates, which show an interesting picture.

Although concentrations of ammoniacal-N were lower during the period October 2013 to May 2014, typically between 8 and $11 \mathrm{mg} / \mathrm{l}$, removal rates were minimal (<10 per cent), no doubt due at least in part to the very high flow rates during this period. However, during warmer months of each year, when flow rates were also reduced, although ammoniacal- $\mathrm{N}$ was typically present at between 12 and $14 \mathrm{mg} / \mathrm{l}$, removal rates of up to 50 per cent were achieved during the period July to September 2013, and again during the summer periods of 2015 and 2016 . At slightly greater flow rates during summer 2014, Ammoniacal-N removal

TABLE 5: Discharge conditions set by Severn Trent Water Limited on 14th August 2014, for wastewaters being discharged into the Upper Cole Valley Sewer.

\begin{tabular}{l|c|c} 
Condition / Determinand & Units & $\begin{array}{c}\text { Discharge consent } \\
\text { set by the EA }\end{array}$ \\
\hline Maximum Discharge Rate & $\mathrm{l} / \mathrm{sec}$ & 2 \\
\hline Dissolved Methane & $\mathrm{mg} / \mathrm{l}$ & $<0.14$ \\
\hline $\mathrm{pH}$ value & $\mathrm{pH}-\mathrm{Value}$ & 6 to 10 \\
\hline $\mathrm{COD}$ & $\mathrm{mg} / \mathrm{l}$ & 300 \\
\hline Ammoniacal-N & $\mathrm{mg} / \mathrm{l}$ & 50 \\
\hline Phosphorus & $\mathrm{mg} / \mathrm{l}$ & 25 \\
\hline Suspended solids & $\mathrm{mg} / \mathrm{l}$ & 200 \\
\hline
\end{tabular}

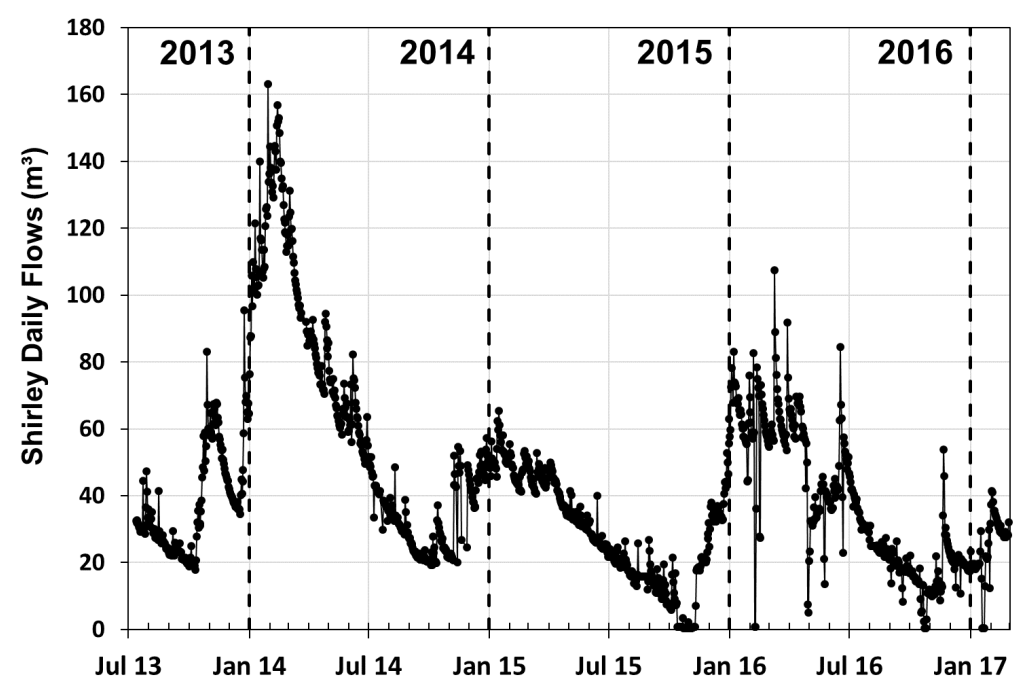

FIGURE 10: Daily volumes treated at Shirley, July 2013 to February 2017 (in m³/d). 


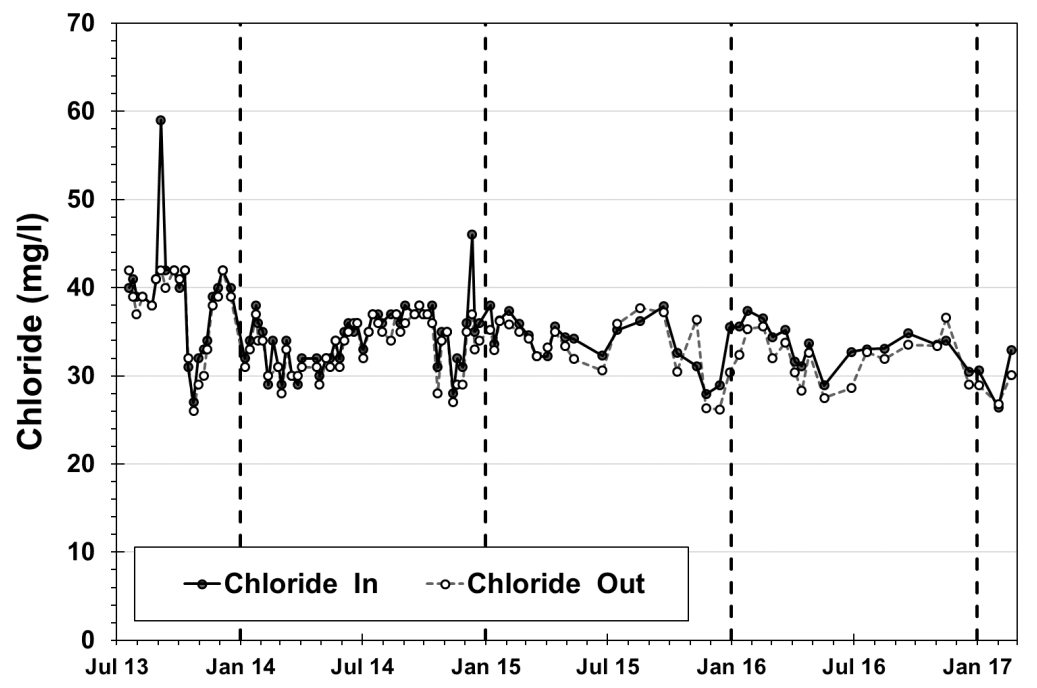

FIGURE 11: Variation in concentrations of chloride during passage through the Shirley reed bed, July 2013 to February 2017 (all results in $\mathrm{mg} / \mathrm{l}$ as chloride).

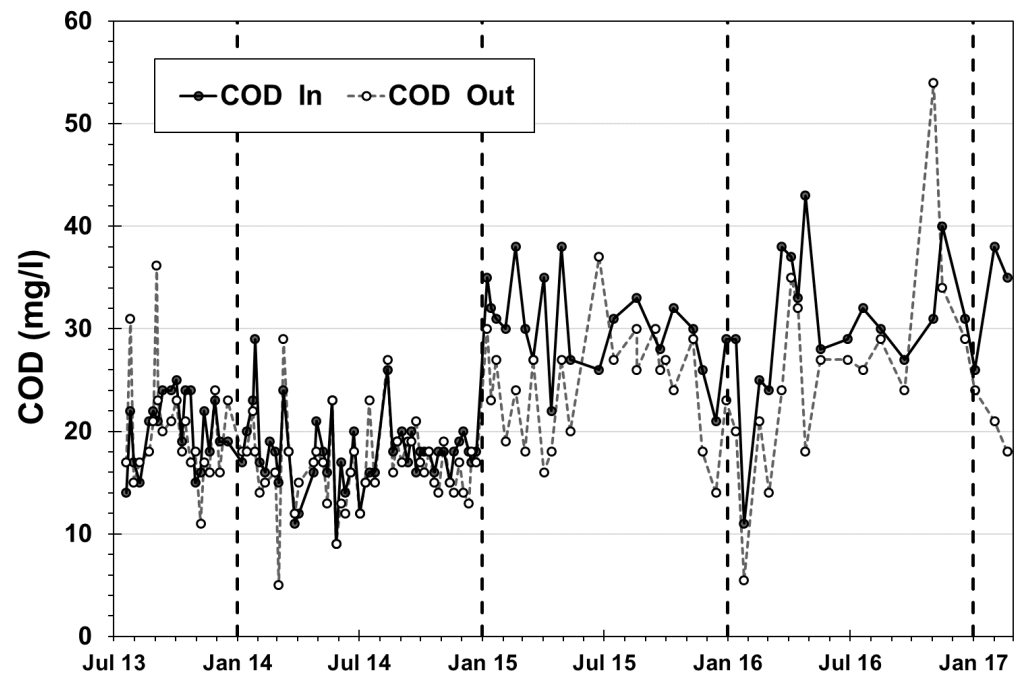

FIGURE 12: Variation in COD values during passage through the Shirley reed bed, July 2013 to February 2017 (all results in mg/l).

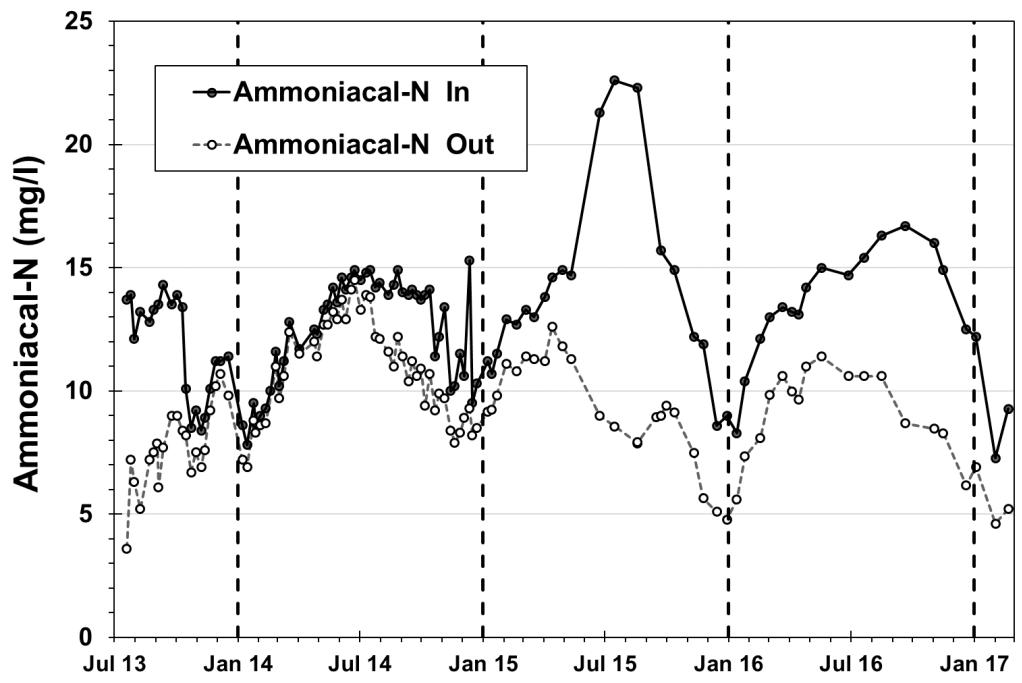

FIGURE 13: Variation in concentrations of ammoniacal-N during passage through the Shirley reed bed, July 2013 to February 2017 (all results in $\mathrm{mg} / \mathrm{l}$ as $\mathrm{N})$. 
rates of up to 25 or 30 per cent were still achieved.

Removal of ammoniacal-N was not any part of the specific design of the reed bed at Shirley, but is clearly being achieved to a significant extent during warmer summer months:

- Summer: 0.9 to $1.0 \mathrm{gN} / \mathrm{m}^{2}$.day

- Winter: 0.4 to $0.5 \mathrm{gN} / \mathrm{m}^{2}$.day

\section{EFFORD LEACHATE TREATMENT PLANT}

\subsection{Background}

Efford is a closed landfill site on the south coast of England, where during early 2003, a leachate treatment system was constructed, which incorporates a fully-automated SBR treatment process, with an engineered reed bed polishing system to achieve very high effluent quality standards. The plant treats up to $150 \mathrm{~m}^{3} / \mathrm{d}$ of strong methanogenic leachate, and more than thirteen years of operational data, collected since 2004 , demonstrate the ability of the plant to meet stringent effluent discharge standards. Of particular interest are results which demonstrate the effectiveness of the reed bed polishing system, in providing removal of residual ammoniacal-N, suspended solids and BOD, allowing safe discharge of treated leachate into a small rural sewage treatment works, which itself discharges effluent into the very sensitive River Avon in Hampshire (Robinson and Olufsen, 2007).

TABLE 6: Discharge conditions set by the Environment Agency for treated leachate at Efford Landfill Site.

\begin{tabular}{|c|c|c|}
\hline Condition / Determinand & Units & $\begin{array}{l}\text { Discharge consent } \\
\text { set by the EA }\end{array}$ \\
\hline Maximum Discharge Rate & $\mathrm{l} / \mathrm{sec}$ & 4 \\
\hline Dissolved Methane & $\mathrm{mg} / \mathrm{l}$ & $<0.14$ \\
\hline $\mathrm{pH}$ value & $\mathrm{pH}$-Value & 6 to 10 \\
\hline COD & $\mathrm{mg} / \mathrm{l}$ & 2,500 \\
\hline Ammoniacal-N & $\mathrm{mg} / \mathrm{l}$ & 80 \\
\hline Chloride & $\mathrm{mg} / \mathrm{l}$ & 2,000 \\
\hline Suspended solids & $\mathrm{mg} / \mathrm{l}$ & 400 \\
\hline Tin & $\mathrm{mg} / \mathrm{l}$ & 0.15 \\
\hline Chromium & $\mathrm{mg} / \mathrm{l}$ & 0.25 \\
\hline Copper, lead, nickel & $\mathrm{mg} / \mathrm{l}$ & 0.50 \\
\hline Zinc & $\mathrm{mg} / \mathrm{l}$ & 1.5 \\
\hline
\end{tabular}

Leachate being produced at the Efford landfill site is strong, with a mean ammoniacal- $\mathrm{N}$ concentration of nearly $600 \mathrm{mg} / \mathrm{l}$, mean COD of just under $1,000 \mathrm{mg} / \mathrm{l}$, chloride of $1,400 \mathrm{mg} / \mathrm{l}$, and alkalinity of $4,000 \mathrm{mg} / \mathrm{l}$. Because of the small size of the receiving sewage treatment works, and the fact that it makes discharges of effluent directly into the Avon, the following effluent discharge conditions in Table 6 were set.

The leachate treatment system was designed to be capable of treating up to $150 \mathrm{~m}^{3} / \mathrm{d}$ of strong leachate and is typical of many similar systems routinely being installed at similar sites globally (e.g. Novella et al., 2004). The plant is shown in Plate 2.

The performance of the Efford plant has exceeded design values, at all times, and all significant determinands in effluent have consistently been almost an order of magnitude below consented limits. Table 7 demonstrates the effectiveness of the SBR treatment, as well as of additional reed bed polishing.

Figure 14 provides details of total monthly volumes of leachate that have been treated by the plant. Since it was commissioned in January 2003, a total volume of 320,000 $\mathrm{m}^{3}$ of leachate has been treated and discharged off-site. In recent years, daily flows have averaged about $62 \mathrm{~m}^{3} / \mathrm{d}$.

\subsection{Polishing of biologically pre-treated leachates to high standards}

Following extensive regular sampling and analysis, the performance of the Efford reed bed in treating key determinands can be observed.

Data for ammoniacal-N in Figure 15, show that con-

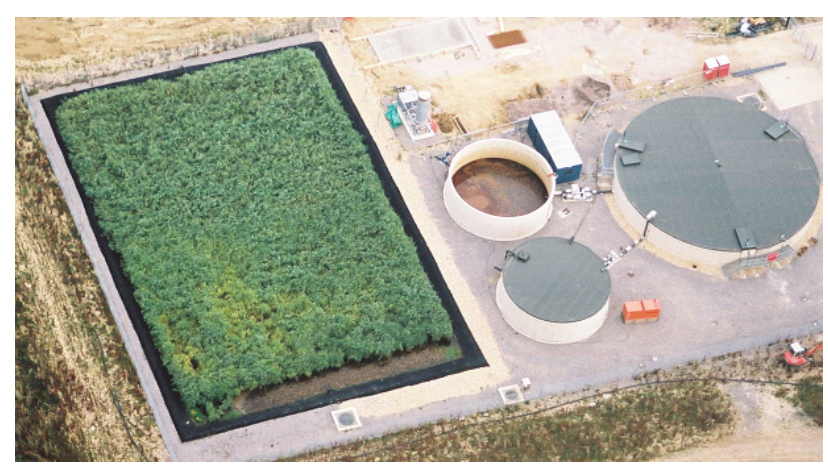

PLATE 2: General arrangement of the Leachate Treatment Plant and reed bed at Efford. (Robinson, 2018).

TABLE 7: Overall performance of Efford Leachate Treatment Plant, in terms of removal of key determinands during the treatment process, January 2003 to February 2017.

\begin{tabular}{|c|c|c|c|c|}
\hline Years & 2003-17 & 2004-17 & 2004-17 & 2004-17 \\
\hline Determinand & COD & $\mathrm{BOD}_{5}$ & $\mathrm{NH}_{4}-\mathrm{N}$ & chloride \\
\hline Raw Leachate Median & 866 & 63.85 & 556 & 1,380 \\
\hline SBR Effluent Median & 234 & 7.77 & 0.8 & 1,350 \\
\hline Reed Bed Effluent Median & 205 & 2.25 & 0.22 & 1,260 \\
\hline Overall removal \% & 76.3 & 96.5 & 99.9 & 8.70 \\
\hline Reed bed removal \% & 12.4 & 71.0 & 72.5 & 6.67 \\
\hline
\end{tabular}

Notes: all results in $\mathrm{mg} / \mathrm{l}$, over 600 samples tested for each result. 
sistently high levels of ammoniacal-N within raw leachate are reliably treated down to concentrations below $10 \mathrm{mg} / \mathrm{l}$, by the SBR system; the reed bed then providing polishing treatment to values below $1 \mathrm{mg} / \mathrm{l}$.

Figure 16 displays a similar pattern for $\mathrm{BOD}_{5}$, where values as high as $300 \mathrm{mg} / \mathrm{l}$ are consistently treated down to below $50 \mathrm{mg} / \mathrm{l}$ by biological SBR treatment, and then to much lower values by passage through the reed bed.

From January 2003 for 18 months, the plant was only treating leachates from older parts of the landfill, typically

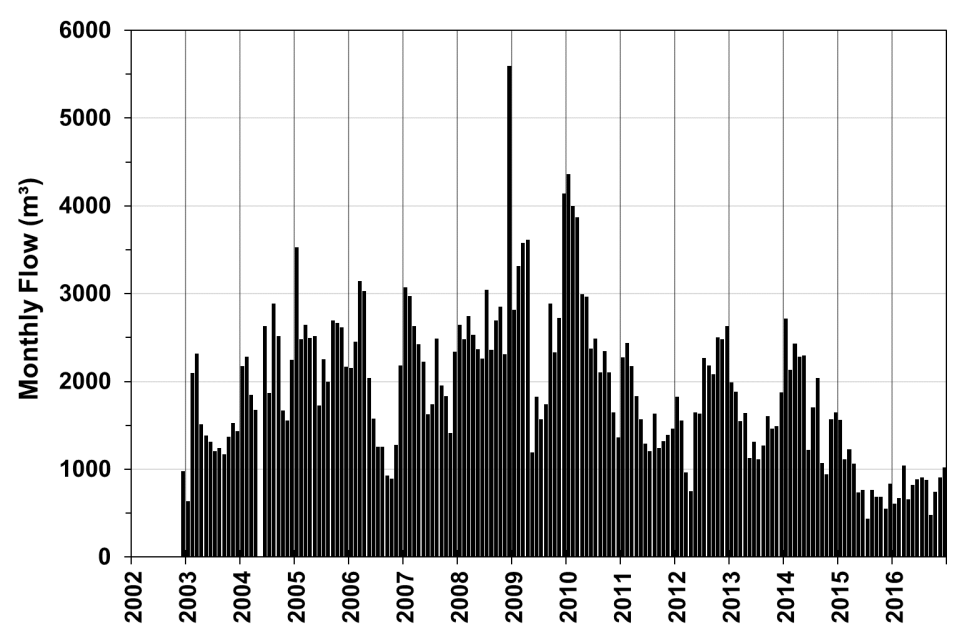

FIGURE 14: Monthly volumes of leachate treated at Efford Leachate Treatment Plant.

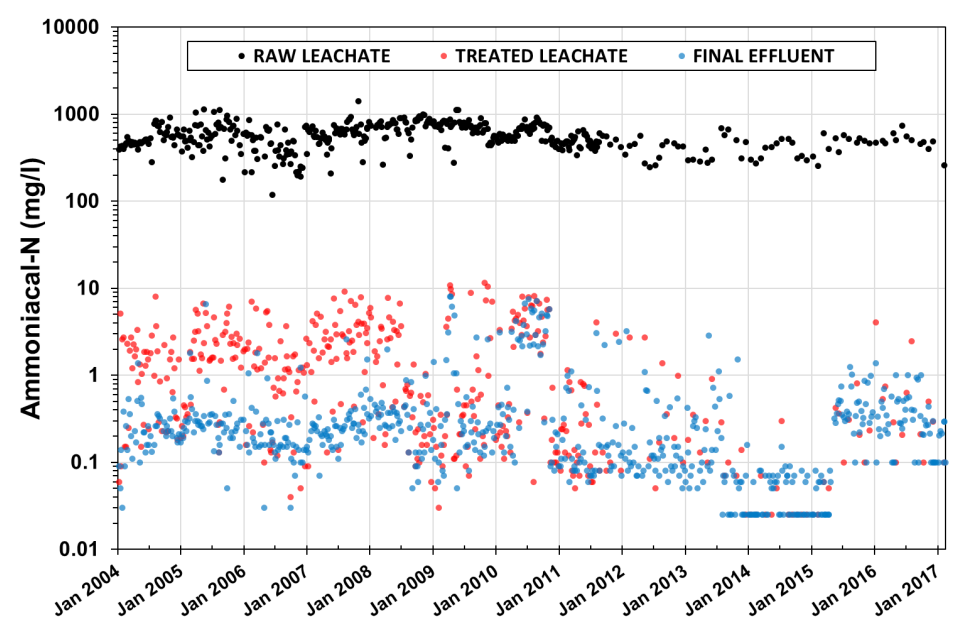

FIGURE 15: Treatment of ammoniacal-N at Efford, January 2004 to February 2017.

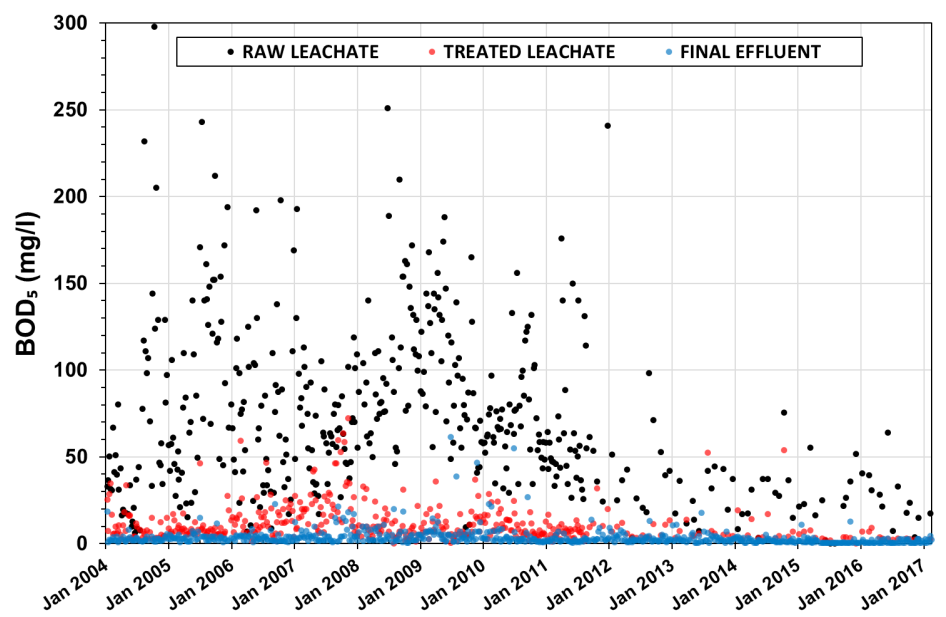

FIGURE 16: Treatment of BOD ${ }_{5}$ at Efford, January 2004 to February 2017. 
containing COD values from 500 to $1200 \mathrm{mg} / \mathrm{l}$, and concentrations of ammoniacal-N from 400 to $700 \mathrm{mg} / \mathrm{l}$. Raw leachate quality was very stable. After July 2004 , variable amounts of stronger leachate, from more recent phases of the landfill, began to be introduced and treated. These leachates were much stronger in both COD and concentrations of ammoniacal- $\mathrm{N}$ (to well above $1,000 \mathrm{mg} / \mathrm{l}$ ). This blending resulted in raw leachate feed that was both stronger (COD values to $2,500 \mathrm{mg} / \mathrm{l}$, ammoniacal- $\mathrm{N}$ to 1,200 $\mathrm{mg} / \mathrm{l})$, and also far more variable in strength.

The plant nevertheless continued to maintain excellent final effluent quality. The value of the reed bed was clear, in dealing with occasional "spikes" in SBR effluent quality, which arose from the more variable quality of daily contaminant loads. This is particularly evident in data for ammoniacal- $\mathrm{N}$ in Figure 15, where levels in final effluent very rarely exceeded $1 \mathrm{mg} / \mathrm{l}$, despite occasional spikes in values in SBR effluent of up to $10 \mathrm{mg} / \mathrm{l}$.

\subsection{Performance}

Treatment of ammoniacal- $\mathrm{N}$ is by means of reliable and complete nitrification to nitrate, typically with about 75 to 90 percent appearing as nitrate- $\mathrm{N}$ in final effluent. The reed bed removes very little nitrate nitrogen, in spite of its excellent performance in taking out residual levels of ammoniacal- $\mathrm{N}$, probably because at flow rates in the order of $100 \mathrm{~m}^{3} / \mathrm{d}$, small reductions in concentration of nitrate- $\mathrm{N}$ in effluent still represent significant supplies of nutrients to the reeds.

\section{SMALL DOLE LEACHATE TREATMENT PLANT}

\subsection{Background}

The final case study will describe use of both vertical and horizontal flow reed beds at the older closed Small Dole Landfill Site in West Sussex, where leachate quality is strongly methanogenic, but year-round contains typically between about 60 and $150 \mathrm{mg} / \mathrm{l}$ of ammoniacal-N. Leachate flow rates have varied between 80 and $700 \mathrm{~m}^{3} / \mathrm{d}$ since 2010, when a full-scale leachate treatment system was designed and constructed, by substantial refurbishment and reconstruction of an existing treatment plant (Robinson, 2017b).

Treatment involves twin Aeration Tanks, which operate within a modified Sequencing Batch Reactor (SBR) system, by means of an external and separate batch Settlement Tank, shown in Plate 3. Because treated leachate must achieve very strict effluent discharge standards, in order to be disposed of into a small, slightly tidal watercourse, which flows around the perimeter of the landfill site, SBR effluent is passed first through Vertical Flow Reed Beds (VFRB), and then Horizontal Flow Reed Beds (HFRB), to provide polishing to high standards (Robinson, 2017b).

The SBR arrangement at Small Dole enables small volumes of leachate, containing 80 to $150 \mathrm{mg} / \mathrm{l}$ of ammoniacal-N, to be diluted within the continuously aerated treatment tanks, so that bacteria are not inhibited. In each 24-hour period, mixed liquor is transferred alternately from each of the 2 aeration tanks every 6 hours, to the settlement tank, before clarified effluent is decanted, and remaining mixed liquor returned to the aerated SBRs.

During discharge of treated leachate from the Settlement Tank, this effluent is fed through vertical and horizontal flow reed beds in series, as a successful effluent polishing process. Reed beds were installed during refurbishment, to provide additional final treatment of the effluent. Effluent then drains into a treated leachate balance tank, designed to enable balancing of discharge flows into the tidal River Adur.

Plate 4 shows the vertical flow reed bed (VFRB) to the right, and the two horizontal flow reed beds (HFRB) to the left, with the river visible in the distance.

Since 2010 , flows of leachate have varied significantly; from $80 \mathrm{~m}^{3} /$ day during summer months, to maximum recorded volumes of up to $700 \mathrm{~m}^{3}$ /day during early 2014 . Typical mean daily leachate flows during summer periods are below $100 \mathrm{~m}^{3} /$ day, while in winter mean daily flows are typically $400 \mathrm{~m}^{3} /$ day. Figure 17 presents detailed daily flow

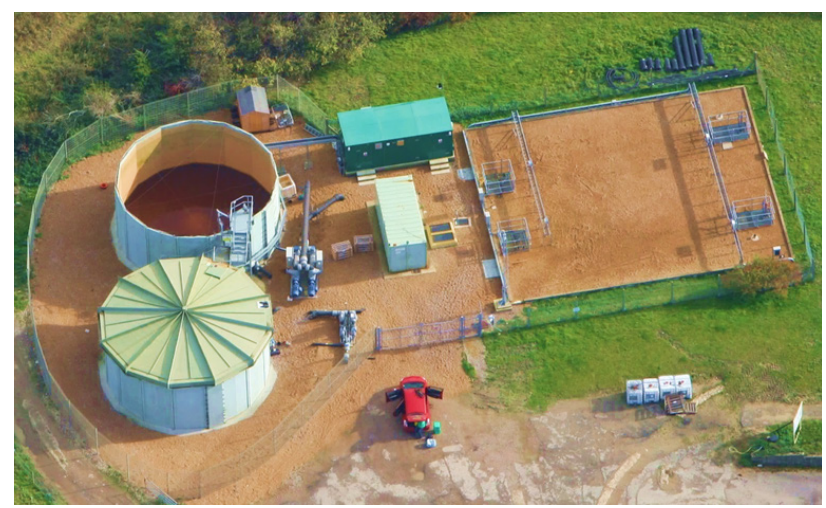

PLATE 3: Aerial view of the updated Small Dole Leachate Treatment Plant, following modifications made in 2010. (Robinson, 2017b).

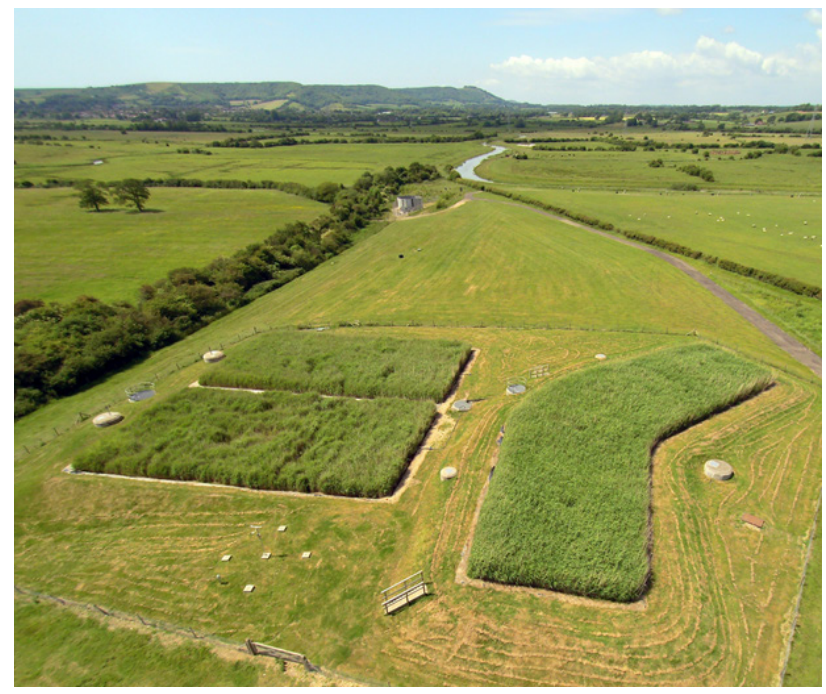

PLATE 4: Aerial view of the Small Dole vertical flow reed bed, and the two parallel horizontal flow reed beds, following construction by Phoenix Engineering in 2010. (Robinson T., 2017). 
data for leachate being collected within the Raw Leachate Balance Tank (RLBT).

Records of the flows of leachate treated between 2011 and 2017 have enabled mean seasonal values for leachate generation to be calculated:

- Spring / Summer: (May to October) $=125 \mathrm{~m}^{3} /$ day

- Autumn / Winter: (November to April) $=280 \mathrm{~m}^{3} /$ day

Because of increased dilution during winter months, leachates generated during summer months are shown to contain more than double the levels of COD and BOD when compared to winter. Similarly, leachates produced during the summer contain $50 \%$ more ammoniacal- $\mathrm{N}$ than those generated during the winter periods.

Table 8 demonstrates that leachates are consistently treated with $\mathrm{COD}, \mathrm{BOD}_{5}$, and ammoniacal-N all treated to very low levels. during both summer and winter periods.

Although strengths of leachate are much lower during winter months, the overall loading of contaminants are significantly higher during winter periods. Despite lower concentrations of contaminants within the leachate being generated, the sheer volume of leachate containing these contaminants, means a higher load is put through the LTP during winter months.

Figure 18 presents data for ammoniacal-N concentrations and loading results. Although concentrations of up to $150 \mathrm{mg} / \mathrm{l}$ are reached during summer months, mean daily loads are much higher during winter periods, exceeding $20 \mathrm{~kg} /$ day of ammoniacal-N during every winter period; and reaching $40 \mathrm{~kg} /$ day during the winter of 2013/14.

Figure 19 compares results for the concentrations of ammoniacal-N within the leachate at Small Dole, with concentrations of nitrate- $\mathrm{N}$ in final effluent. Because values for ammoniacal- $\mathrm{N}$ in leachate, and nitrate- $\mathrm{N}$ in effluent match so well, this shows that all ammoniacal nitrogen is being effectively fully nitrified. Combined with trace levels of ammoniacal-N in final effluent (presented in Table 8 earlier), this demonstrates the success of the system in achieving complete nitrification, as required by the discharge consent.

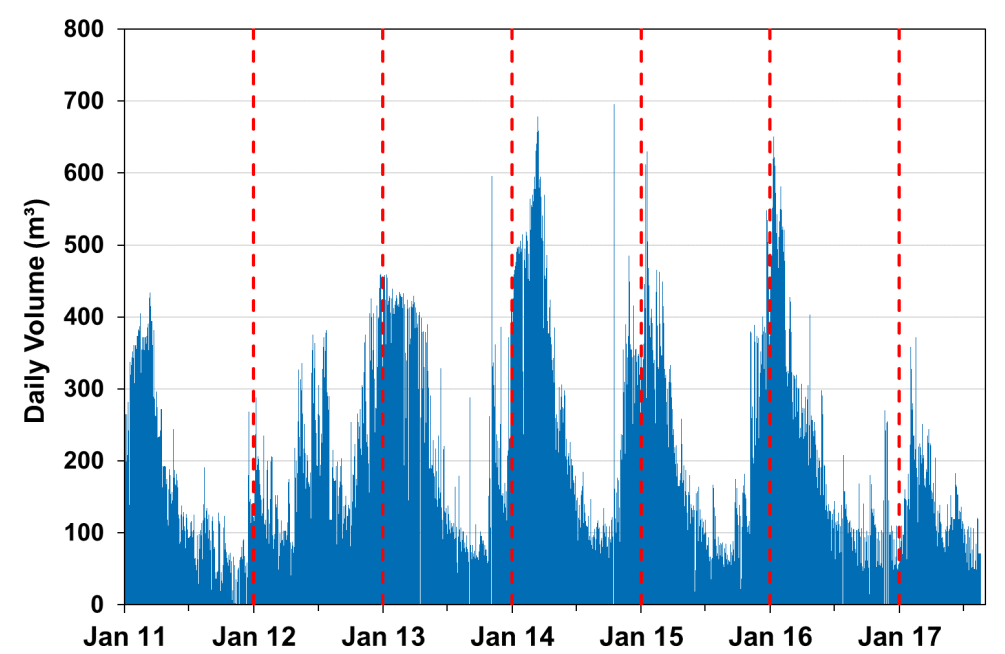

FIGURE 17: Daily Raw Leachate Flows at Small Dole from January 2011 to August 2017 (m3). (Robinson, 2017b).

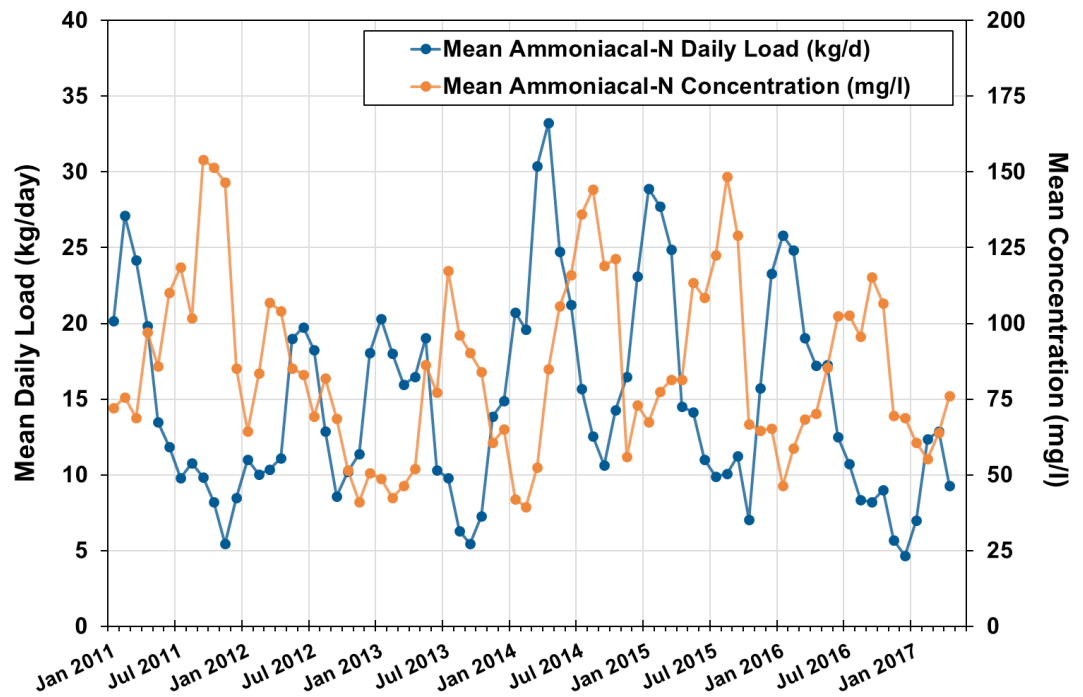

FIGURE 18: Ammoniacal-N mean concentration (mg/l) and mean daily load (kg/day) at the Small Dole reed bed. (Robinson, 2017b). 


\subsection{Performance}

The refurbished plant has performed extremely well, always achieving discharges that are compliant with the site's Environmental Permit, and the combined reed bed polishing system readily provides a back-up to the main biological treatment plant. Research work is continuing (see Robinson, 2017b; Wilson et al., 2017) to examine in detail the contribution to treatment of the individual system components.

Results obtained at Small Dole demonstrate how effectively SBR and reed bed treatment options can be combined, to treat large volumes of leachates and achieve stringent discharge consents; allowing final effluents to be discharged to sensitive watercourses. It remains a hope that ultimately, the reed beds alone may provide a passive system, capable of managing all leachates from the site.

\section{OVERALL SUMMARY}

All four reed beds, at Monument Hill, Shirley, Efford and Small Dole, continue to perform successfully during 2017, ensuring that effluents from each site readily satisfy the discharge consents set by regulatory authorities.

The Monument Hill reed bed provides removal of suspended solids and iron to very high standards, with significant levels of reduction in concentrations of ammoniacal-N; whilst the degradation of residual levels of $\mathrm{BOD}_{5^{\prime}}$ COD and mecoprop is also evident. This removal is most effective and important during warmer summer months, when a stream receiving final effluent is most sensitive.

The Shirley reed bed has removed all methane from leachate entering it, even when flows were more than double design rates during early 2014 (see Figure 20). Seasonal removal of ammoniacal-N has taken place (up to 50 percent during 2013, 2015 and 2016), but this was not part of the design purpose of the bed, and as more data are obtained, it has been possible to obtain valuable loading rate data for this removal.

A reed bed receiving treated leachate discharged from an SBR system operating at Efford Landfill Site continues to provide very successful removal of any residual levels of ammoniacal-N and $\mathrm{BOD}_{5}$.

Table 9 summarizes the removal that each of the reed beds provide for key determinands. All beds demonstrate similar levels of removal for suspended solids, and high corresponding removal of iron (over $90 \%$ removal at each site).

Each of the reed beds demonstrate significant removal of ammoniacal-N, with Monument Hill and Efford both removing nearly $80 \%$ of $\mathrm{NH}_{4}-\mathrm{N}$, while Shirley removes over a quarter (26\%), on a seasonal basis.

Shirley reed bed is very successful at removing high initial levels of dissolved methane (95\% removal), as per the intended requirements; ensuring that methane remains well below the $0.14 \mathrm{mg} / \mathrm{l}$ discharge consent.

Following biological treatment of stronger leachate at Efford, the reed bed there provides additional effluent polishing, by removing close to $70 \%$ of residual $\mathrm{BOD}_{5}$.

TABLE 8: Variations in strength of Leachate produced at Small Dole. (Robinson, 2017b).

\begin{tabular}{|c|c|c|c|c|}
\hline Season & \multicolumn{2}{|c|}{ Summer Period } & \multicolumn{2}{|c|}{ Winter Period } \\
\hline Months & \multicolumn{2}{|c|}{ May - October } & \multicolumn{2}{|c|}{ November - April } \\
\hline Samples (no.) & \multicolumn{2}{|c|}{160} & \multicolumn{2}{|c|}{168} \\
\hline Sample & Leachate & Effluent & Leachate & Effluent \\
\hline COD & 1,377 & 99.0 & 548 & 77.9 \\
\hline BOD & 50.4 & 1.30 & 20.9 & 0.84 \\
\hline Ammoniacal-N & 104 & 0.22 & 69.0 & 0.24 \\
\hline Nitrate-N & 1.17 & 101 & 0.50 & 71.9 \\
\hline Chloride & 606 & 655 & 460 & 391 \\
\hline
\end{tabular}

TABLE 9: Comparison between the performance of three reedbed systems.

\begin{tabular}{|c|c|c|c|c|c|c|c|c|c|c|}
\hline \multirow{2}{*}{$\begin{array}{l}\text { Determinand } \\
(\mathrm{mg} / \mathrm{l})\end{array}$} & \multicolumn{3}{|c|}{ Monument Hill Reedbed } & \multicolumn{3}{|c|}{ Shirley Reedbed } & \multicolumn{4}{|c|}{ Efford Leachate Treatment Plant } \\
\hline & Raw & Final Eff & $\%$ & Raw & Final Eff & $\%$ & Raw & SBR & Final Eff & $\%$ \\
\hline COD & 54 & 30 & 44.4 & 22.9 & 20.5 & 10.5 & 963 & 239 & 207 & 13.4 \\
\hline $\mathrm{BOD}_{5}$ & 3 & 3 & 0.00 & 1.23 & 1.15 & 6.50 & 74.0 & 11.43 & 3.58 & 68.7 \\
\hline $\mathrm{NH}_{4}-\mathrm{N}$ & 17.8 & 3.7 & 79.2 & 12.8 & 9.49 & 25.9 & 579 & 5.95 & 1.08 & 81.9 \\
\hline Alkalinity & 640 & 505 & 21.1 & 393 & 381 & 3.18 & 3,692 & 811 & 774 & 4.56 \\
\hline Suspended Solids & 68 & 6 & 91.2 & - & 11.71 & NA & 95.1 & 111 & 31.1 & 71.9 \\
\hline Sodium & 52 & 51 & 1.92 & 25.36 & 24.8 & 2.17 & 867.9 & 1,364 & 1,271 & 6.78 \\
\hline Chloride & 92 & 76 & 17.4 & 34.9 & 33.8 & 3.15 & 1,444 & 1,427 & 1,319 & 7.57 \\
\hline Methane & - & - & - & 1.2 & 0.06 & 95.0 & 0.172 & 0.005 & 0.004 & 25.8 \\
\hline Iron & 10.1 & $<0.05$ & $>99.5$ & 6.29 & 0.56 & 91.1 & 13.06 & 9.11 & 0.469 & 94.9 \\
\hline
\end{tabular}

Notes: all results in $\mathrm{mg} / \mathrm{l} ; \%$ = Percentage removal; Final Eff = Mean concentration in final effluent . 


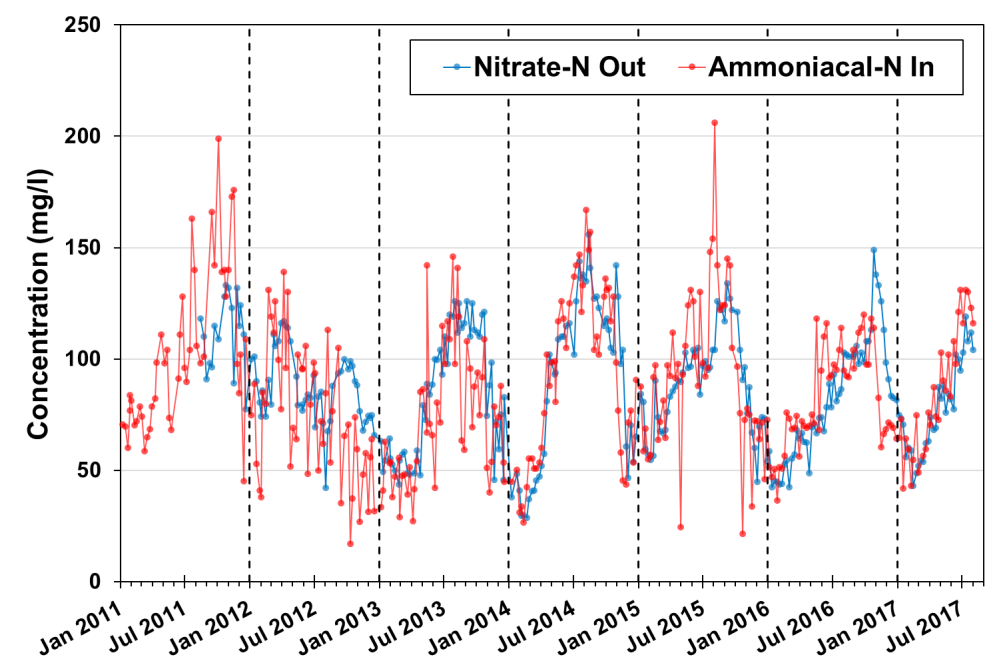

FIGURE 19: Concentrations of ammoniacal-N within raw leachate and Nitrate-N within final effluent at Small Dole, January 2011 to August 2017 (mg/l). (Robinson, 2017b).

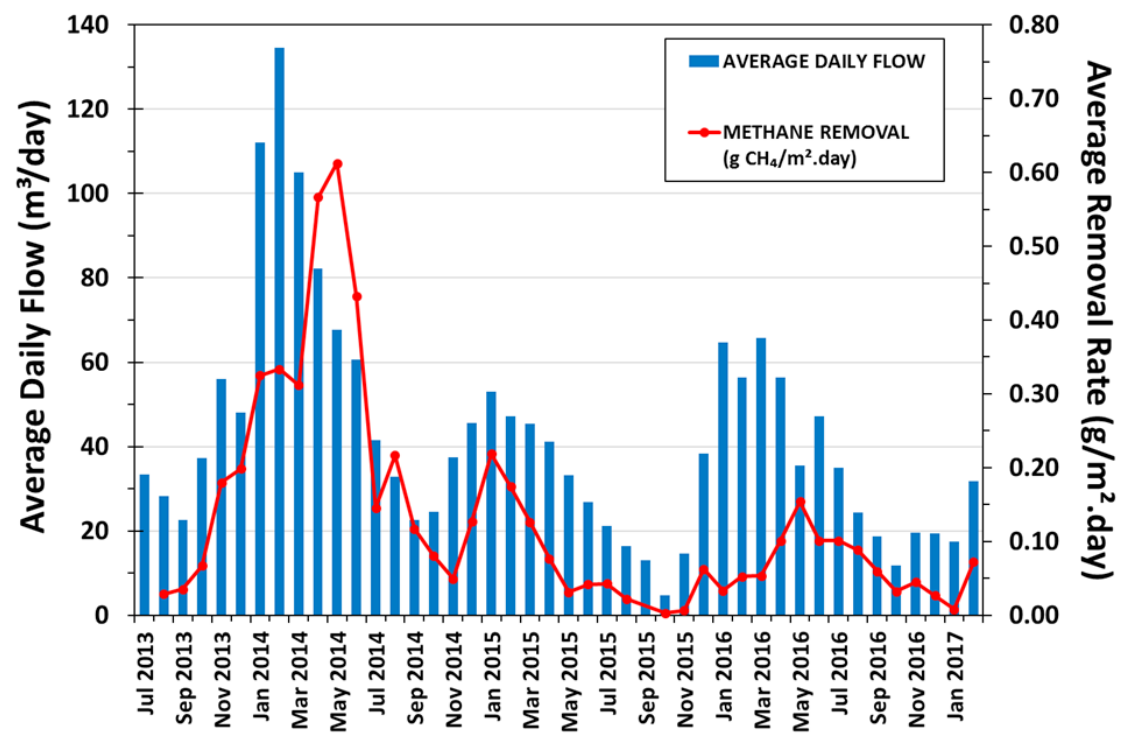

FIGURE 20: Removal of dissolved methane by the Shirley Reed Bed in terms of grams of methane per m2 of reed bed area, July 2013 to July 2016 (Robinson, 2017a).

\section{CONCLUSIONS}

Reed bed treatment systems are becoming increasingly common on UK landfill sites, although relatively few detailed data have been published from the operation of such systems.

The case studies presented in this report demonstrate that well-designed reed bed systems are able to operate consistently, reliably, and cost-effectively, to meet stringent effluent discharge standards for specific contaminants at all times. Detailed operating data that this paper provides provide great confidence to both treatment plant operators, and to landfill regulators.

In future, similar schemes will have widespread application at many closed landfill sites, where low levels of $\mathrm{BOD}_{5}, \mathrm{COD}$, ammoniacal- $\mathrm{N}$ and methane, in weaker leachates, will need reducing to below consented levels. Additionally, metals such as iron, associated with suspended solids, can be readily removed in a similar horizontal flow reed bed system; principally by oxidation and filtration. For unmanned closed sites, a reed bed is a reliable, low-cost leachate treatment solution, requiring little maintenance, supervision and operator input. Nevertheless, it is important to recognise that for leachates containing more than about $10 \mathrm{mg} / \mathrm{l}$ of ammoniacal-N, complete removal to low levels cannot be guaranteed during winter months.

Reed bed polishing systems such as those operated at Efford and Small Dole for many years, will continue to be incorporated at many future leachate treatment plants, to achieve additional removal of residual low concentrations of ammoniacal-N (less than $5 \mathrm{mg} / \mathrm{l}$ or maybe $10 \mathrm{mg} / \mathrm{l}$ ), and of $\mathrm{BOD}$ values following biological treatment.

\section{ACKNOWLEDGEMENTS}

Wiltshire County Council has been responsible for the 
remedial works that have been put in place at Monument Hill landfill site, and the co-operation of Sandra Truscott of the Council, in the preparation of this paper, is much appreciated.

The Environment Agency (formerly the National Rivers Authority), South Western Region, was extremely helpful, both in discussions that led to the solution adopted at Monument Hill, and also in making available the results from their independent sampling program for inclusion in the paper.

The author gratefully acknowledges the support of Worcestershire County Council in work on the Shirley Reed bed project, especially Matthew Reed and Kristy Thomas, in the collection of extensive effluent and leachate data.

Sincere thanks are due to staff of Hampshire County Council, who have led the implementation of the Efford leachate treatment plant as part of extensive remediation works at the site. Mike Banner of Veolia Limited has been involved in operation of the Efford plant on behalf of the Council, for many years.

Support has been provided by CEMEX in work on the Small Dole Leachate Treatment Plant, especially Kevin Wilson, Neil Meredith, and Dick Sibley for their enthusiasm and site-specific knowledge, and to Karen Magee in the provision of extensive leachate and effluent flows and analytical data. He is also extremely grateful to the plant operator Stephen Fish, and to colleagues at Phoenix Engineering, who designed and modified the Small Dole Leachate Treatment Plant.

\section{REFERENCES}

Baun, D.L., Christensen, T.H. (2004). Speciation of Heavy Metals in Landfill Leachate: A Review. Waste Management \& Research. 22 (1), pp 3-23.

Carville, M.S., Last, S.D., Olufsen, J.S., Robinson, H.D. (2003). Characterisation of Contaminant Removal achieved by Biological Leachate Treatment Systems: paper presented to Sardinia 2003, the Ninth International Waste Management and Landfill Symposium, 6 - 10 October 2003, S. Margherita di Pula, Cagliari, Sardinia, Italy, 11pp.

Cooper, P. (1999). A review of the design and performance of vertical-flow and hybrid reed bed treatment systems. Water Science and Technology. 40 (3), pp 1-9.

Cooper, P. and Green, B. (1995). Reed bed treatment systems for sewage treatment in the United Kingdom - The first 10 years' experience. Water Science and Technology. 32 (3), pp 317-327.

Cooper, P., Smith, M. and Maynard, H. (1997). The design and performance of a nitrifying vertical-flow Reed Bed Treatment System. Water Science and Technology. 35 (5), pp 215-221.

Environment Agency (2007). Guidance for the Treatment of Landfill Leachate. Integrated Pollution Prevention and Control (IPPC). Sector Guidance Note IPPC S5.03, February 2007, pp 1-182.

Heron, G. and Christensen, T.H. (1992). Degradation of the herbicide mecoprop in an aerobic aquifer determined by laboratory batch studies. Chemosphere. 24 (5), pp 547-557.

Jensen, D.L. and Christensen, T.H. (1999). Colloidal and dissolved metals in leachates from four Danish landfills. Water Research. 33 (9), pp 2139-2147.

Jensen, D.L., Ledin, A. and Christensen, T.H. (1999). Speciation of heavy metals in landfill-leachate polluted groundwater. Water Research. 33 (11), pp 2642-2650.

Morris, M. and Herbert, R. (1997). The design and performance of avertical flow reed bed for the treatment of high ammonia, low suspended solids organic effluents. Water Science and Technology. 35 (5), pp 197-204.
Novella P., Haider S., Strachan L., Robinson H. and Last S. (2004). Full scale landfill leachate treatment in South Africa: the use of aerobic SBR processes and reed bed systems. Paper presented to WasteCon 2004, the biennial International Waste Congress and Exhibition of the Institute of Waste Management of Southern Africa, 11-15 October 2004, Sun City, South Africa. In the Proceedings of the conference and on CD-ROM, $11 \mathrm{pp}$.

Robinson H.D. (1993). The treatment of landfill leachates using reed bed systems. Paper presented to 'Sardinia '93', Fourth International Landfill Symposium, S. Margherita di Pula, Sardinia, Italy, 11-15 October 1993, In: Proceedings, Volume I, pp 907-922.

Robinson H.D. (1996). A review of the Composition of Leachates from Domestic Wastes in Landfill Sites. Report No. CWM 072/95, published by the Waste Technical Division of the Environment Agency, in the series "The Technical Aspects of Controlled Waste Management", 500pp, August 1996, available priced £75 from Environment Agency Dissemination Centre, c/o WRC plc, tel: 01793 511711, or by E-mail from publications@wrcplc.co.uk.

Robinson H.D. and Knox K. (2001). Pollution Inventory discharges to sewer or surface water from landfill leachates: Final Report to the UK Environment Agency, by Enviros and Knox Associates. Ref REGCON 70, May 2001. 19pp plus appendices and figures.

Robinson, H.D. and Knox, K. (2003). Updating the landfill leachate Pollution Inventory tool. R\&D Technical Report No. P1-496/TR(2), prepared for the UK Environment Agency by Enviros Consulting and Knox Associates, February 2003, 56pp.

Robinson, H.D., Walsh, T. and Carville, M S. (2003). Advanced leachate treatment at Buckden landfill, Huntingdon, UK. Journal of Environmental Engineering and Science, National Research Council, Canada, 2, (4), 255-264, July 2003.

Robinson H.D., Harris G. and Truscott, S. (2007). Use of reed-bed systems to provide environmentally-friendly control of leachate from old landfills: Ten years of experience from a site in Wiltshire. Paper presented to Torbay 2006, The Annual Conference and Exhibition of CIWM, "Changing the Face of Waste Management", Paignton, June 2006. Published in Communications in Waste and Resource Management, March 2008, 9, (1), pp 31-41.

Robinson H.D. and Olufsen J.S. (2007). Full biological treatment of landfill leachate: a detailed case study at Efford Landfill, in the New Forest, Hampshire (UK). Paper presented to Sardinia 2007, the 11th International Waste Management and Landfill Symposium, held at Forte Village, S. Margherita di Pula, Cagliari, Italy, 1-5 October 2007, In, proceedings page 203 and on CD-ROM.

Robinson H.D., Olufsen J.S., Thomas K., Reed M., Robinson T.H. (2015a). The use of reed bed systems for methane removal from landfill leachates. Proceedings Sardinia 2015, Fifteenth International Waste Management and Landfill Symposium, S. Margherita di Pula, Cagliari, Italy; 5-9 October 2015, CISA, Italy.

Robinson H.D. (2017a). Removal of dissolved methane and sulphides from landfill leachates. Paper presented to Sardinia 2017, the 16th International Waste Management and Landfill Symposium, held at Forte Village, S. Margherita di Pula, Cagliari, Italy, 2-6 October 2017, In, proceedings and on CD-ROM.

Robinson T.H. (2015b). Aerobic Biological Treatability Studies on Landfill Leachate using Nitrification and Denitrification. Final Year Dissertation, (Supervisor Professor Kevin Hiscock). School of Environmental Sciences, University of East Anglia (UEA), Norwich, UK. April 2014, 66 pages plus appendices. Available from the UEA Library.

Robinson T.H. (2017b). Robust and reliable treatment of leachate at a closed landfill site in Sussex, UK. Paper presented to Sardinia 2017, the 16th International Waste Management and Landfill Symposium, held at Forte Village, S. Margherita di Pula, Cagliari, Italy, 2-6 October 2017, In, proceedings and on CD-ROM.

Robinson T.H. (2018). Robust and Reliable Treatment of Leachate at a closed landfill site in Sussex, UK. Detritus, Multidisciplinary Journal for Waste Resources and Residues. Detritus Volume 1, pp 116-121.

Wilson K.S. (2017). Minimising the cost of environmental monitoring around landfill sites using modern data management systems - a case study of CEMEX UK. Paper presented to Sardinia 2017, the 16th International Waste Management and Landfill Symposium, held at Forte Village, S. Margherita di Pula, Cagliari, Italy, 2-6 October 2017, In, proceedings and on CD-ROM. 